\title{
"RELIEF" PROVISIONS IN THE REVENUE ACT OF 1943
}

\author{
BY JAMES E. FAHEY $\uparrow$
}

THE Revenue Act of $1943^{1}$ is an anomaly in the framework of income $\operatorname{tax}$ legislation. ${ }^{2}$ Its most obvious distinction lies in the manner of its enactment. It is the first revenue raising measure ever to be vetoed by a president and the first ever to be passed over veto. The political storm which engulfed Congress and the President over the bill's passage centered in large measure over the so-called "relief" provisions found in the bill. These provisions alternately have been defended as accomplishing the correction of existing inequities in the law and assailed as providing loopholes enabling certain favored individuals and industries to avoid their equitable share in financing the war. A scrutinization of these controversial provisions in the light of the situations which they were designed to change may serve to focus the issue more clearly for the reader whose opinions are yet to be crystallized.

Specifically, the President's veto message ${ }^{3}$ criticized five "relief" provisions in the bill as being special privilege measures. They were the provision for non-recognition of gain or loss on corporate reorganizations carried on under court supervision and the concomitant "basis" provision, ${ }^{4}$ the extension of percentage depletion to certain minerals which were theretofore denied its use, ${ }^{\overline{3}}$ a provision making optional to taxpayers in the timber or logging business an accounting procedure which would enable them to treat the cutting of their timber as the sale of a capital asset, $^{6}$ the extension of favored excess profits tax treatment formerly given only to producers of minerals and timber to producers of natural gas, $^{7}$ and a broadening of the existing exemption of air mail carriers from excess profits taxes. ${ }^{8}$

$\dagger$ Member of the Kentucky Bar; Lecturer in Taxation, University of Louisville Law School.

1. Pub. L. No. 235, 78th Cong., 2d Sess. (Feb. 25, 1944) (hereinafter cited as Revenue Act of 1943).

2. Even its title deviates from the former scheme of nomenclature of federal revenue acts since the Act applies in the main only to taxable years commeneing on or aiter January 1,1944 . Its only connection with 1943 seems to be that most of the legislative worl: was done during that year and that there may have been hope for its enaetment prior to December 31, 1943.

3. N. Y. Times, Feb. 23,1944 , p. 1, col. 1.

4. Revenue Act of 1943, $\$ 121$.

5. Revenue Act of 1943, $\S 124$.

6. Revenue Act of $1943, \S 127$.

7. Revenue Act of $1943, \S 208$.

8. Revenue Act of 1943, § 209. 


\section{Reorganization of Certain Insolvent Corporations}

Not long after the enactment of the 1913 federal income tax law, a conception of taxable income in respect to corporate distributions was formalized by the Supreme Court in a series of cases involving exchanges of corporate property and securities wherein the interests of the stockholder-taxpayers were changed in form rather than in substance. It was argued by the taxpayers that such inconsequential changes in their interests could not constitute a realization of income as that term had been defined by the Court in the earlier stock-dividend case of Eisner v. Macomber. ${ }^{9}$ The argument was rejected, however, the Court holding that no matter how slight the changes were, a taxable transaction had occurred. ${ }^{10}$

Such a conceptualistic view at once clashed with the common understanding of realized income. The business man could hardly be persuaded that a tax incident had occurred as long as his investment was still subject to the perils which had always jeopardized it, even though he might hold slightly different evidence of his savings. Congressional relief came quickly in the form of the "reorganization" section of the federal income tax law.

The underlying purposes of the reorganization provisions were to relieve certain types of "realized" income from recognition for tax purposes and thus permit readjustment of business enterprise unhampered by a premature tax. ${ }^{11}$ The increased value of the assets involved was not freed from tax. Rather, by means of appropriate "basis" provisions, ${ }^{12}$

9. 252 U. S. 189 (1920). Additional shares of common stock were issued to holders of such stock, and an amount equivalent to the par value of the new issue was transferred from surplus account to capital stock account. The Court held that a stockholder who had participated in the stock dividend had not acquired any of the company's assets for his separate use and benefit, but, rather, that his original investment and the corporate accumulations derived from its use still remained subject to business risks which might lead to the wiping out of the entire investment. Accordingly, receipt of the diviclend stock did not sever anything from the res and, therefore, no income was realized.

10. United States v. Phellis, 257 U. S. 156 (1921) (a new company organized under the laws of a different state held essentially different from the old corporation from which it received its assets); Marr v. United States, 268 U. S. 536 (1925) (similar to United States v. Phellis, stupra); Cullinan v. Walker, 262 U. S. 134 (1923) (a holding company held essentially different from an operating company) ; Rockefeller $v$.United States, 257 U. S. 176 (1921) (a subdivision. of assets into two corporations held taxable because the stockholders became the owners of stock in two distinct business ventures). In Weiss v. Stearn, 265 U. S. 242 (1924), the new corporation was organized in the same state and was engaged in the same business with the same management. Further, there was no attempt to segregate a surplus by transferring it to the new corporation. This case was distinguished from the preceding decisions upon these grounds.

11. See Sen. Rep. No. 275, 67th Cong., 1st Sess. (1924); H. R. Rep. No. 350, 67th Cong., 1st Sess. (1924). See also the famous Gregg Statement, N. Y. Times, Jan. 5, 1924, p. 1, col. 2.

12. INT. REv. CODE $\S 113(a)(6), 113(a)$ (7) (1939). 
the gain or loss was merely postponed until a transaction occurred which was more nearly in line with the common view of a tax incident. ${ }^{13}$

Moreover, it was the theory of the reorganization provisions that they should operate to relieve against the recognition of gain or loss only in situations where the taxpayer's proprietary interest in the affected corporation continued in some modified corporate form. ${ }^{13}$ This restriction, prior to the amendments contained in the Revenue Act of $1942,{ }^{15}$ was accomplished by permitting tax free exchanges of corporate stocks or securities for other stocks or securities ${ }^{10}$ or property ${ }^{17}$ only where the transaction took place pursuant to a plan of "reorganization." The term "reorganization" was then defined to include only situations in which the interest of the taxpayer continued and in which the imposition of a tax would seem, unreasonable. ${ }^{18}$

Prior to the Revenue Act of 1942 these situations were: (1) A statutory merger or consolidation covered by part (A) of the definition; (2) a merger or consolidation accomplished without reference to statutes in which one corporation acquired at least 80 per cent of the outstanding shares or substantially all the properties of another corporation

13. An illustration will best explain the theory. Suppose $A$ purchases one share of stock in $M$ Company, incorporated in state $X$, at a cost of $\$ 100$. Thereafter $M$ forms a new corporation, $N$, under the laws of state $Y^{\prime}$; and, pursuant to an offer by the new corporation, $A$ exchanges his one share of the old II Company stock for two shares of common, worth $\$ 100$ each, in the new $N$ Company. Through similar transactions $N$ becomes the owner of all of M's stock and causes its liquidation in kind. Without the "reorganization" provisions, the exchange made by $A$ would be a taxable transaction, gain being recognized as the difference between the cost to $A$ of his share of $M$ stock and the fair marlict value of the $N$ stock when received. Under the "reorganization" provisions, no gain is reeognized. Since the new corporation acquired "at least 80 per centum of the voting stod: and at least $\$ 0$ per centum of all other classes of stock" of the old corporation by giving its own voting stock in exchange therefor, a reorganization resulted under section $112(\mathrm{~g})$ (1) (B) of the Internal Revenue Code. Under Code section 112(b) (3), which provides that "no gain or loss shall be recognized if stock or securities in a corporation a party to a reorganization are, in pursuance of the plan of reorganization, exchanged solely for stock or securities in ... another corporation a party to the reorganization," no gain or loss would be recognized to the old stockholders on the exchange of old stod: solely for new stock. The transfer of assets and dissolution of the old company is to be vieved as part of the reorganization and not as a taxable liquidation. George Whittell \& Co., 34 B. T. A. 1070 (1936).

Under section 113(a) (6) of the Internal Revenue Code, the basis for calculating gain or loss in subsequent "recognizing" transactions on the two new shares of $N$ common stock will be the cost of the old stock, $\$ 100$, spread over the new stock, that is, $\$ 50$ per share. If $A$ sells the new shares for $\$ 110$ each, a taxable gain of $\$ 60$ per share is recognized.
14. See note 11 supra.
15. 56 STAT. 798 (1942).
16. INT. REv. CoDE $\S 112$ (b) (3) (1939).
17. INT. Rev. CoDE $\$ 112$ (b) (4) (1939).
18. Int. Rev. CODE $\S 112(\mathrm{~g})$ (1939). See note 11 stpro. 
in exchange solely for its voting stock, covered by parts (B) and (C) of the definition; (3) the transfer by one corporation of a part of its assets to another corporation controlled by the transferor, covered by part (D) of the definition; (4) the recapitalization of a corporation wherein the stockholders and creditors agreed to increase or clecrease the corporation's capital or debts, or both, covered by part (E) of the definition; (5) a change of the corporate identity, character, or state of incorporation, covered by part (F) of the definition. ${ }^{10}$ Thus the key to qualification for the tax benefit was the definition of "reorganization." 20

Upon this legislative framework, the courts, through a pliant attitude in their interpretations of technicalities in the statute and a mindfulness of the purposes which Congress had sought to accomplish, trod a middle of the road path, in the main dealing effectively with ingenious tax evaders, ${ }^{21}$ and at the same time permitting legitimate transactions to receive the bounties of the statute..$^{22}$

But the technicalities of the reorganization provisions and the inverted pyramid of appellate procedure in tax cases, whereby the decisions of one tribunal (the Board of Tax Appeals ${ }^{23}$ ) are appealed to many different higher forums (the various circuit courts of appeals), inevitably caused

19. Section $112(\mathrm{~g})(1)$ of the Internal Revenue Code provides:

"The term 'reorganization' means (A) a statutory merger or consolidation, or (B) the acquisition by one corporation, in exchange solely for all or a part of its voting stock, of at least 80 per centum of the voting stock and at least 80 per centum of the total number of shares of all other classes of stock of another corporation; or (C) the acquisition by one corporation, in exchange solely for all or a part of its voting stock, of substantially all the properties of another corporation, but in determining whether the exchange is solely for voting stock: the assumption by the acquiring corporation of a liability of the other, or the fact that property acquired is subject to a liability, shall be disregarded, or (D) a transfer by a corporation of all or a part of its assets to another corporation if immediately after the transfer the transferor or its shareholders or both are in control of the corporation to which the assets are transferred, or (E) a recapitalization, or (F) a mere change in identity, form, or place of organization, however effected."

20. Fahey, Income Tax Definition of "Reorganization" (1939) 39 CoL. L. REV. 936.

21. For example, the judicially imposed doctrines of "business purpose," announced in Gregory v. Helvering, 293 U. S. 465 (1935), and developed in Helvering v. Minnesota Tea Co., 302 U. S. 609 (1938); the continuity of interest doctrine judicially refined in Pinellas Ice \& Cold Storage Co. v. Commissioner, 287 U. S. 462 (1933), and LeTulle v. Scofield, 308 U. S. 415 (1940) ; and the "step reorganization" case: Helvering v. Elkhorn Coal Co., 95 F. (2d) 732 (C. C. A. 4th, 1938) ; Elect. Securities Corp. v. Commissioner, 92 F. (2d) 593 (C. C. A. 2d, 1937) ; A. W. Mellon, 36 B. T. A. 977 (1937) (wherein it was sought to strip undesired assets from the transferor corporations before the main reorganization was entered into).

22. Commissioner v. Neustadt's Trust, 131 F. (2d) 528 (C. C. A. 2d, 1942).

23. October 21, 1942, the name of the Board was changed to The Tax Court of the United States. 56 Star. 957, Revenue Act of 1942, c. $619, \S 504$. 
confusion and uncertainty with respect to the tax consequences of reorganization. Perhaps the greatest confusion and the greatest uncertainty occurred in cases involving court sponsored reorganizations of insolvent corporations.

Such reorganizations are generally carried out either pursuant to the applicable provisions of the Amended Bankruptcy Act ${ }^{24}$ or under the general equity powers of courts. Both procedures at once met with tax difficulties. In the first case it may be preliminarily observed that reorganizations carried out under the bankruptcy statute are not consummated pursuant to a statute of the type referred to in part (A) of the income tax definition of reorganization. ${ }^{25}$ This would seem apparent on the face of part (A). ${ }^{26}$ The "statutory merger or consolidation" there referred to means combination, whereas the bankruptcy reorganization has as its purpose the injection of financial vitality into but a single corporation.

Thus those reorganizations carried out pursuant to the Amended Bankruptcy Act were in no better position income-tax-wise than the insolvent reorganized by the equity court. Both were relegated to qualifying for the tax benefit of the "reorganization" sections under those clauses which deal with the acquisition solely for z'oting stock by one corporation of substantially all the property of another or with the transfer of property to a corporation immediately thereafter controlled by the transferor or its stockholders. This was because the only feasible type of reorganization in cases of defaulting corporations involved the foreclosure of the creditors' liens and the formation of a new company to take over the assets and conduct the business, the interests of all types of creditors and

24. Originally under section 77, 47 STAT. 1474 (1933), 11 U. S. C. 205 (1940), and section 77B, 48 Stat. 912 (1934); and later under section 77 and chapter $\times$, 52 Sr.1T. 883 (1938), 11 U. S. C. c. X (1940).

25. The Bureau of Internal Revenue at an early date took the pusitiun that reorganizations carried out under old section 77B of the Amended Bankruptey Act, 48 Star. 912 (1934), were not statutory mergers or consolidations within the meaning of the incume tax "reorganization" definition. Communication to Columbia Fuel \& Irun Curpuratiun, Denver, Colo., from W. T. Sherwood, Acting Deputy Commissioner, Burcau uf Internal Revenue, March 4, 1937.

26. See note 19 supra. Part (A) of the definition of a reorganizatiun pruvides that the term means "a statutory merger or consolidation." The Treasury originally interpreted the words "statutory merger or consolidation" to refer only to mergers and cunsolidations effected pursuant to the corporation laws of a state, territory, or the District of Columbia. U. S. Treas Reg. S6, Art. $112(\mathrm{~g})-2$. But in a Treasury Decision issued soon after the regulations under the 1934 Act were published, reurganizations under the federal statutes were recognized as coming within this part of the definition. T. D. 4585, XIV-2 Cuns. Buln 54 (1935). This provision was continued in the regulations under the 1936 and 1938 Acts. U. S. Treas. Reg. 86, Art. 112(g)-2; U. S. Treas. Reg. 101, Art. $112(\mathrm{~g})-2$; and in regulations promulgated under the Internal Revenue Code. U. S. Treas. Reg. 103, $\$ 19.112(\mathrm{~g})-2 ;$ U. S. Treas. Reg. 111, $\$ 29.112(\mathrm{~g})-2$. 
of the stockholders being pared down in proportion to the priorities of their claims. ${ }^{27}$ Qualification of this type of reorganization of insolvent corporations under parts (B), (C), and (D) of the definition presented a perplexing problem to the courts.

Such reorganizations were to be measured by the continuity of interest doctrine, first judicially imposed on the pre-1934 definition ${ }^{28}$ of reorganization by Pinellas Ice \& Cold Storage Company v. Commissioner ${ }^{20}$ and later written into the law with a bold hand by the Revenue Act of $1934^{30}$ with the requirement that the acquiring (new) corporation must give "solely voting stock" in exchange for the transferee (insolvent) corporation's stock or properties. Briefly stated, this doctrine demanded that the equity interest of the insolvent transferring corporation's stockholders must continue in the new acquiring corporation.

After a checkered career in the circuit courts of appeals, ${ }^{31}$ it was de-

27. Use of the old corporate structure with qualification under the "recapitalization" provision of the definition was fairly clear, although little used. Old stockholders were not inclined to vote for necessary amendments to the articles of incorporation which forcclosed their participation in the corporation as reorganized. See SEN. REp. No. 627, 78th Cong., 1st Sess. (1943) 51. The "change in identity, form or place of organization" clause contemplated too insubstantial a shifting of corporate interests to apply.

28. Those parts of the definition which relate to transfers to a controlled corporation, recapitalizations, and changes in corporate identity, character, or state of incorporation, (see page 462 supra), have not been changed since the extensive revision carried out by the Revenue Act of 1924. Important changes, however, were made in the Revenue Act of 1934 relative to that part of the definition which deals with mergers and consolidations. In the 1924 Act these terms included, in addition to their general connotation, "the acquisition by one corporation of at least a majority of the voting stock and at least a majority of the total number of shares of all other classes of stock of another corporation." 43 Stat. 253, 257, Revenue Act of 1924, $\$ 203(\mathrm{~h})(1)(A)$. This provision was continued in the Revenue Acts of 1928, 45 STAT. 791, 818, $\$ 112$ (i) (1)(A), and of 1932, 47 Stat. 196, §112(i) (1) (A). The 1934 Act, however, confined them strictly to statulory mergers and consolidation. 48 StAT. 704, Revenue Act of 1934, $\$ 112$ (g)(1)(A). This provision was continued in subsequent revenue acts and appears in the Code. INT. REv. CODE, $\$ 112$ (g) (1) (A) (1939). The 1934 Act also provided that the definition of "reorganization" should include "the acquisition by one corporation in exchange solely for all or a part of its voting stock: of at least 80 per centum of the voting stock and at least 80 per centum of ... all other classes of stock of another corporation, or of stbstantially all the properties of another corporation." 48 STAT. 680, 704, Revenue Act of 1934, $\$ 112(\mathrm{~b})(1)(B)$. This provision was continued in subsequent revenue acts and appears in the Code. INT. Rev. Code $\$ 112(\mathrm{~g})(1)$ (B) (1939).

29. 287 U. S. 462 (1933).

30. See note 28 supra.

31. For cases holding that there had been compliance with the pre-1934 definition, see Helvering v. Alabama Asphaltic Limestone Co., 119 F. (2d) 819 (C. C. A. 5th, 1941); Commissioner v. Marlborough House, Inc., 118 F. (2d) 511 (C. C. A. 9th, 1941), 55 HARv. L. Rev. 292; Commissioner v. Newberry Lumber \& Chem. Co., 94 F. (2d) 447 (C. C. A. 6th, 1938) ; Commissioner v. Kitselman, 89 F. (2d) 458 (C. C. A. 7th, 1937). For cases holding that there had been no compliance, see Helvering v. New President Corp., 122 F. (2d) 92 (C. C. A. 8th, 1941), 55 Harv. L. Rev. 292; Palm Springs Holding Corp. v. Commissioner, 119 F. (2d) 846 (C. C. A. 9th, 1941). 
cided by the Supreme Court ${ }^{32}$ that under the pre-1934 definition ${ }^{33}$ a reorganization had occurred despite the fact that old stockholders were eliminated from participation in the new company's securities because the bondholders had, upon the moment they invoked the processes of the law (institution of bankruptcy, receivership, or foreclosure proceedings) to enforce their rights, stepped into the shoes of the old stockholders. The subsequent sale "did nothing but recognize officially what had before been true in fact." 34

Thus the equities of the true owners of the old corporation continued in the newly formed one and the continuity of interest doctrine was satisfied. But the pre-1934 definition and its judicially imposed requisite of continued interest did not present the strictness found in the requirement that the acquiring corporation exchange solely voting stock, written into the definition by the Revenue Act of $1934,{ }^{35}$ and when the identical issue was presented to the court under the amended definition, "solely voting stock" was held to mean exactly what it says. ${ }^{30}$ Accordingly, a reorganization failed to qualify under part $(B)$ of the income tax definition, not because old stockholders were frozen out, but because they were given stock purchase warrants, something other than voting stock..$^{3 i}$ Nor did the reorganization qualify under part (C) because control as defined by the law ${ }^{38}$ was not in the old corporation or its "stockholders." While the court, for continuity of interest purposes, was willing to view the bond-

32. Bondholders Committee v. Commissioner, 315 U. S. 189 (1942); Palm Springs Holding Corp. v. Commissioner, 315 U. S. 185 (1942); Helvering v. Alabama Asphaltic Limestone Co., 315 U. S. 179 (1942).

33. See note 28 supra.

34. Helvering v. Alabama Asphaltic Limestone Co., 315 U. S. 179, 184 (1942).

35. See note 28 sitpra. Section 213 of the Revenue Act of 1939, 53 Sтsт. 862, 871, added to clause (B) of the definition: "but in determining whether the exchange is solely" for voting stock, the assumption by the acquiring corporation of a liability of the other, or the fact that property acquired is subject to a liability, shall be disregarded." This amendment avoided the undesirable effects of United States v. Hendler, 303 U. S. 564 (1938), rehearing denied, 304 U. S. 588 (1938), and Helvering v. Minnesota Tea Co., 302 U. S. 609 (1938). See Fahey, supra note 20, at 960-61; H. R. REp. No. 855, 76th Cong., 1st Sess. (1939) 18-20; SEN. Rep. No. 648, 76th Cong., 1st Sess. (1939) 3. This is the only exception to the voting stock requirement of clauses (B) and (C).

36. Helvering v. Southwest Consolidated Corp., 315 U. S. 194 (1942). See also Central Kansas Tel. Co. v. Commissioner, 4 C.C.H. 1944 Fed. Tax Serv. I 9249 (C. C. A. 10th, 1944).

37. Helvering v. Southwest Consolidated Corp., 315 U. S. 194 (1942). The Court also found that a "reorganization" was prevented because non-consenting security holders were paid off in cash, also something other than voting stocl:

38. By section 112(h) of the Revenue Act of 1934, 48 STAr. 680, 704, the term "control" was defined to mean "the ownership of stock possessing at least 80 per centum of the total combined voting power of all classes of stock entitled to vote and at least 80 per centum of the total number of shares of all other classes of stods in the corporation." This definition was continued in subsequent revenue acts and appears in the Code. Ixi. REv. CODE $§ 112(\mathrm{~h})$ (1939). 
holders as "stepping into the shoes of the old stockholders," it was unwilling to interpret the word "stockholders" in part (C) as meaning anyone except stockholders in the old corporation.

This situation was subsequently confused by Helvering v. Cement Investors. ${ }^{39}$ This case took the view that the properties of the insolvent corporation were to be considered as reaching the new corporation by two distinct steps: (a) from the old corporation to the foreclosing lien holders, and (b) from the foreclosing lien holders to the new corporation.

Those who owned the properties immediately prior to the transfer to the new corporation (the bondholders) were in "control" of the new company immediately after the transfer and therefore, even though the definition of "reorganization" was not met, this transaction was saved from tax by a specific exemption akin to the reorganization provisions. ${ }^{40}$ Hence an asserted deficiency based upon this exchange failed, although if the deficiency had been asserted in connection with the first step, it undoubtedly would have been sustained. With the tax "reorganization" benefits restricted to those court sponsored reorganizations which shift proprietary interest through the medium of voting stock alone, the number of such reorganizations which could qualify shrunk to imperceptibility. ${ }^{41}$

While qualification of the reorganization under the income tax reorganization sections in the foregoing cases was the primary problem for the Court's attention, it was not the ultimate objective of the taxpayers. In cases where a "reorganization" occurs, the acquiring corporation takes as its basis for the calculation of taxable gain or loss in subsequent "recognizing" transactions, the basis which the acquired properties bore in the hands of the transferor corporation. ${ }^{42}$ This basis is also to be used in determining such deductions from ordinary income as depreciation and bad debts ${ }^{43}$ and in computing the acquiring corporation's credit for excess profits tax purposes. ${ }^{44}$

39. 316 U. S. 527 (1942).

40. 49 Stat. 1648, 1678, Revenue Act of 1936, § 112(b) 5. This section provided for non-recognition of gain or loss upon the transfer of property to a corporation by one or more persons in exchange for stock or securities in the corporation. It has been continued in all subsequent revenue acts and appears in the Code. INT. REv. CODE \$112(b) (5) (1939). The effect of the transaction upon the taxable situation of the new company was not before the Court. Cf. 49 Stat. 1648, 1682, Revenue Act of 1936, \&113(a)(6) ; INT. Rev. CODE, $\$ 113(\mathrm{a})(6)$ (1939).

41. The devolution of a fair, equitable, and feasible plan of reorganization for an intricate business corporation with many classes of stockholders and many classes of creditors presents a herculean task when a free hand is given the reorganizer. When leeway is restricted by the dictates of a tax law which demands that the property of the old company be acquired by issuance to creditors and stockholders of solely voting stock in the newly formed corporation, the problem becomes insurmountable.

42. See note 13 supra.

43. Int. Rev. Code $\$ 113$ (a) (6), 113(a) (7) (1939).

44. INT. Rev. Code $\S 718$ (a) (2) (Supp. 1941). 
As a result, the tax consequences of a reorganization are not confined to the mere question of recognition of gain or loss to stockholders in the particular transaction itself, but extend many years into the future of the new corporation affecting recurring tax liabilities of many millions of dollars. Since the vast majority of insolvent corporate reorganizations involve companies with assets of high cost and low market value, this facet of the "reorganization" question is the one of paramount importance. $^{45}$ The question thus posed for legislative answer was: Should the corporation as reorganized keep the benefits of the old insolvent company's high tax basis?

Congress decided that it should and recognizing the uncertainties besetting an insolvent court-reorganized corporation on this score under existing law as interpreted by the Supreme Court, set about to accomplish the result desired by amending the "reorganization" sections. The first step came in the Revenue Act of 1942. As a part of a program to assist debt-ridden railroad corporations, ${ }^{\mathbf{} 6}$ this law provided for the carryover of the transferring corporation's tax basis in cases where the properties of railroad and street railway corporations were transferred to other railroad or street railway corporations organized or made use of to effect a plan of reorganization approved by a court in a proceeding under section 77 of the Amended Bankruptcy Act or in an equity receivership proceeding. ${ }^{47}$ In the Revenue Act of $19+3$, this benefit was extended to all

45. See Helvering v. Southwest Consolidated Corp., 315 U. S. 104 (1942); Bundholders Committee v. Commissioner, 315 U. S. 189 (1942) ; Palm Springs Holding Corp. v. Commissioner, 315 U. S. 185 (1942) ; Helvering v. Alabama Asphaltic Limestone Co., 315 U. S. 179 (1942).

46. Another feature of this program may be found in seetion 114 (b) of the Revenue Act of 1942, 56 StAт. 798, 811, which excluded from gross income amounts realized as the result of the cancellation or modification of indebtedness of railroads pursuant to court order in proceedings under section 77 of the Amended Bankruptcy Act or in equity receivership proceedings.

47. Section 142(a) of the Revenue Act of 1942, 56 Star. 798, 838, addcd paragraph 9 to section 112 (b) of the Internal Revenue Code. The new section stated:

"Loss not recognized on certain railroad reorganizations.-No loss shall be recognized if property of a railroad corporation, as defined in section $77 \mathrm{~m}$ of the National Bankruptcy Act, as amended, is transferred, after December 31, 1939, in pursuance of an order of the court having jurisdiction of such corporation-

"(A) in a receivership proceeding, or

"(B) in a proceeding under section 77 of the National Banlsuptcy Act, as amended, to a railroad corporation, as defined in section $77 \mathrm{~m}$ of the National Bankruptcy Act, as amended, organized or made use of to effectuate a plan of reorganization approved by the court in such proceeding. The term 'reorganization', as used in this paragraph, shall not be limited by the definition of such term in subsection (g)."

Section $142(b)$ of the Revenue Act of 1942 added paragraph 20 to section 113(a) of the Internal Revenue Code. The new section stated:

"Property acquired by railroad corporation.-If the property of a railroad corporation, as defined in section $77 \mathrm{~m}$ of the National Banliruptcy Act, as amend- 
corporations undergoing insolvency reorganization under court supervision. The new Act accomplished the benefit by providing that no gain or loss should be recognized upon the transfer of property pursuant to an order of a court having jurisdiction of the corporation in a receivership proceeding or in a proceeding under section $77 \mathrm{~B}$ or Chapter $\mathrm{X}$ of the Amended Bankruptcy Act to a corporation organized or made use of to effectuate a plan of reorganization approved by the court in exchange solely for stock or securities in the transferee, ${ }^{48}$ and further, that

ed, was acquired after December 31,1939, in pursuance of an order of the court having jurisdiction of such corporation-

"(A) in a receivership proceeding, or

"(B) in a proceeding under section 77 of the National Bankruptcy Act, as amended, and the acquiring corporation is a railroad corporation, as defined in section $77 \mathrm{~m}$ of the National Bankruptcy Act, as amended, organized or made use of to effectuate a plan or [of] reorganization approved by the court in such proceeding, the basis shall be the same as it would be in the hands of the railroad corporation whose property was so acquired. The term 'reorganization', as used in this paragraph, shall not be limited by the definition of such term in section $112(\mathrm{~g}) . "$

No loss was to be recognized in such transactions, but the non-recognition of gain was still to be measured by the appropriate Internal Revenue Code provision, chief of which was the "reorganization" definition.

48. Revenue Act of $1943, \S 121$ (a). This section added paragraph (b) (10) to section 112 of the Internal Revenue Code. The new matter provided:

"Gain or Loss Not Recognized on Reorganization of Corporations in Certain Receivership and Bankruptcy Proceedings.-No gain or loss shall be recognized if property of a corporation (other than a railroad corporation, as defined in section $77 \mathrm{~m}$ of the National Bankruptcy Act, as amended) is transferred, in a taxable year of such corporation beginning after December 31, 1933, in pursuance of an order of the court having jurisdiction of such corporation--

"(A) in a receivership, foreclosure, or similar proceeding, or

"(B) in a proceeding under section 77B or Chapter X of the National Bankruptcy Act, as amended, to another corporation organized or made use of to effectuate a plan of reorganization approved by the court in such proceeding, in exchange solely for stock or securities in such other corporation."

Section 121 (b) of the 1943 Act added new subsection (1) to section 112 of the IIIternal Revenue Code. The new subsection stated:

"Exchanges by Security Holders in Connection with Certain Corparate Reorganizations.-

"(1) Getseral rule.-No gain or loss shall be recognized upon an exchange consisting of the relinquishment or extinguishment of stock or securities in a corporation the plan of reorganization of which is approved by the court in a proceeding described in subsection (b) (10), in consideration of the acquisition solely of stock or securities in a corporation organized or made use of ta effectuate such plan of reorganization.

"(2) Exchange occurring in taxable years beginning prior to January 1 , 1943.-If the exchange occurred in a taxable year of the person acquiring such stock or securities beginning prior to January 1, 1943, then, under regulations prescribed by the Commissioner with the approval of the Secretary, gain or loss shall be recognized or not recognized- 
in all such transactions the basis of the property acquired in the hands of the acquiring corporation should be the same as it would be in the hands of the corporation whose property was so acquired. ${ }^{40}$

Compliance with the income tax definition of reorganization is no longer required, ${ }^{50}$ but the continuity of interest doctrine is still maintained, although not with the strictness of the voting stock demands of the definition. Thus in bankruptcy or state court liquidations-proceedings involving the sale of the insolvent's assets to interests supplying new capital used to discharge obligations of the old corporation-the acquiring corporation must use its cost as a tax basis for the properties in its hands. ${ }^{51}$

The Act further provides that no gain or loss shall be recognized upon the exchange of stock or securities of the old corporation solely for stock or securities in the new corporation; and relinquishment or extinguish-

"(A) to the extent that it was recognized or not recognized in the final determination of the tax of such person for such taxable year, if such tax was finally determined prior to the ninetieth day after the date of the enactment of the Revenue Act of 1943; or

"(B) in cases to which subparagraph (A) is not applieable, to the extent that it would be recognized or not recognized under the latest treatment of such exchange by such person prior to December 15,1943 , in connection with his tax liability for such taxable year."

Where the consideration for the transferred properties consists of other property or money as well as stock or securities, then gain, but not loss, is recognized to the extent of the "boot" received. Revenue Act of 1943, $\$ 121$ (d). The assumption of liabilities by the acquiring corporation is not considered to be other property. See note 35 supro. It is specifically provided that section 270 of the Amended Bankruptcy Act and section 113 (b) (3) of the Internal Revenue Code shall not apply to reduce the basis by the amount of any indebtedness cancelled in the proceeding.

49. Section 121 (c) of the Revenue Act of 1943 added to section 113 (a) of the Internal Revenue Code, paragraph 22, which provides the corollary basis provision. The new paragraph states:

"Property acquired on reorganization of certain corporations.-If the property was acquired by a corporation upon a transier to which section 112 (b) (10), or so much of section 112 (d) or (e) as relates to section $112(\mathrm{~b})(10)$ is applicable, then, notwithstanding the provisions of section 270 of the National Banliruptcy Act, as amended, the basis in the hands of the acquiring corporation shall be the same as it would be in the hands of the corporation whose property was so acquired, increased in the amount of gain recognized to the corporation whose property was so acquired under the law applicable to the year in which the acquisition occurred, and such basis shall not be adjusted under subsection (b) (3) by reason of a discharge of indebtedness pursuant to the plan of reorganization under which such transfer was made"

Technical amendments harmonized the other "reorganization" sections with the changes effected by subsections (a), (b), and (c) of section 121.

50. Revenue Act of 1943, $\$ 121$ (d) (4).

51. Two of Judge Simons' decisions for the Sixth Circuit Court of Appeals are illustrative: Templeton's Jewelers, Inc. v. United States, 126 F. (2d) 251 (1942) ; Mascot Stove Co. v. Commissioner, 120 F. (2d) 153 (1941). 
ment of stock or securities in consideration for the receipt of new shares is held to be an exchange. ${ }^{52}$

The amendments to the Code are made retroactive as if they had been a part of the law from the Revenue Act of $1934,{ }^{53}$ but they are to have no effect on income tax liability for any year beginning before January 1,1943 . Thus if the reorganization occurred at a time when, under existing law, gain or loss was recognized, such recognition and its tax consequences will not be affected, even though the year in which the reorganization occurred is still open. Similarly, the basis for the acquiring corporation's properties, determined under the old law, will not be changed until its first taxable year commencing after January 1, 1943. But for that year and all subsequent years its basis will be determined under the new law and the corporation may assume its transferor's basis. ${ }^{54}$

The considerations which led Congress to enact these changes are in the main persuasive. So long as the continuity of interest requirement is preserved, the enterprise realistically is the same after the reorganization as before. It would seem fair to give the same tax status to the new company as that held by the insolvent. Prior to the amendments contained in the Revenue Act of 1943, this result was made to depend upon legal technicalities, often beyond the control of the insolvent company or

52. The reorganization may take the form of (a) a transfer of property from the old corporation to its bondholders, upon surrender of their bonds, with a subsequent transfer of the property to a new corporation in exchange for its stock, or (b) an exchange bctween bondholders and the new corporation-bonds for stock-followed by the surrender of the bonds for the property of the old corporation. In either event, section 121(b) of the Revenue Act of 1943 considers the transaction as an exchange of securities of the old corporation for securities of the new corporation. With respect to those cases in which the exchange occurred in a taxable year beginning prior to January 1, 1943, recognition or non-recognition of the gain or loss upon the exchange is made to depend upon whether or not tax liability for the year involved has been finally determined. If it has, such determination is not to be disturbed. If it has not, then recognition of gain or loss upon the exchange is made to depend upon the position last maintained by the taxpayer prior to December 15, 1943, relative to the recognition or non-recognition of gain or loss upon the transaction. Revenue Act of $1943, \S 121$ (b) (2).

53. The Act which effected the restrictive changes in the "reorganization" definition. See note 28 supra.

54. Revenue Act of $1943, \S 121$ (e). An illustration will best serve to explain the retroactive effect of the new provisions. Assume that in $1938 M$ corporation became insolvent and through a court sponsored reorganization of the pattern dealt with herein, emerged as the $N$ corporation. This transaction, under Helvering v. Southwest Consolidated Corp., 315 U. S. 194 (1942), would not be a "reorganization," gain or loss would be recognized to stockholders, and $N$ could not use $M$ 's tax basis for the assets it acquired. Under the retroactive provisions of the new law, tax liability crystallized in 1938 would not be disturbed, even thoúgh 1938 is still open. $N$ corporation's deductions for depreciation on its newly acquired assets for 1938 to 1942 , calculated on the low basis acquired in what in 1938 was a taxable transaction, will remain unchanged. But $N$ 's depreciation deduction for 1943 and all subsequent years will be determined under the new law, that is, upon $M$ 's tax basis. 
its security holders, with the result that corporate reorganizations substantially identical from a practical standpoint received widely different tax treatment. Arbitrary and non-economic distinctions also appeared in the tax treatment accorded prosperous corporations able to control the detail of their reorganizations and insolvent corporations which were forced to accept a plan of reorganization which was the product of an effort to satisfy creditors and win court approval and which had to ignore technicalities required by the "reorganization" sections. Such discriminations were aggravated ones, since the financially weaker enterprise would seem to merit the better tax position. In these respects the amendments accomplished salutary equality, a commonplace of tax law too often ignored by Congress and the Department of the Treasury.

To the extent that general corporate business policy is determined by the impact of federal taxes, the amendments had a certain quieting effect on many corporations, the products of court sponsored reorganizations, whose tax basis for properties received in the reorganization was in doubt. On the whole, the amendments hardly "aftord ... [an] indefensible special privilege." 55

\section{Extension of Percentage Depletion to Minerals Formerly Denied Its UsE}

Sound accounting practice has long recognized that the gradual exhaustion of a body of ore is an element of expense which should be taken up, as are operating expenses, in each fiscal period during which minerals continue to be won from the mine. ${ }^{50}$ No true picture of net income from the accountant's standpoint can be arrived at without an allowance of this character. Thus, the capital invested in mineral property must be apportioned over the period that the ore is mined and recovered from the earnings of the mine before it can be said that the owner of the mine has realized income.

But the Supreme Court, at an early date, rejected this accounting analysis. Relying on its earlier decision holding constitutional the 1913 income tax law, ${ }^{57}$ in which it decided that the provisions of the Sixteenth Amendment conferred no new power of taxation, but simply removed the requirement of apportionment in respect of income taxation (a tax which Congress had the complete and plenary power to levy from the beginning), the Court decided that taxation of the gross income from mines was not a direct tax on capital which had to be apportioned. ${ }^{\text {ss }}$ Since such a tax was within the authority of the Sixteenth Amendment, depletion

55. President's Veto Message, N. Y. Times, Feb. 23, 1944, p. 1, col. 1.

56. Miontgonsery, Auditrang Theory and Practice (1916) 566; Saliers, Accous:tANT'S HANDEOOK (1923) 461.

57. Brushaber v. Union Pacific R. R., 240 U. S. 1 (1916).

58. U. S. Const. Art. I, $\$ 9$, 
deductions were therefore relegated to the category of other deductions, that is, made dependent upon legislative grace..$^{50}$

But Congress, since the first income tax law, has provided that there may be deducted from gross income allowances for the depletion of minerals in which the taxpayer holds an economic interest. ${ }^{00}$ These allowances have been afforded upon three primary methods of computation: (a) cost depletion, (b) discovery depletion, and (c) percentage depletion.

Cost Depletion. This method allows recovery to the taxpayer of the cost or March 1, 1913, value of the ore tax free. The investment of the taxpayer is to be taken as his adjusted basis for the ore, as provided in section 113(b) of the Internal Revenue Code, for the purposes of determining the gain upon the sale or other disposition of such property. ${ }^{01}$ After this investment is ascertained, it is to be divided by the number of units of the mineral contained in the deposit. The divisor used in this computation must necessarily be an estimate based upon information available to the taxpayer's geologists at the date of reporting his income tax liability. The quotient is then multiplied by the units sold during the year, and the total depletion deduction is thus ascertained. ${ }^{22}$ When the taxpayer's basis thus arrived at is exhausted, his allowance for depletion ceases, since his cost has been recovered, and all else is profit.

Discovery Depletion. This method allows recovery to the taxpayer without tax, as reward for his exploration in unproven tracts, of the fair market value of the ore within thirty days after its discovery. Here again, computation of the deduction involves an estimate of the number of units contained in the deposit. After this estimate is made, it is multiplied by the then selling price of the unit and discounted over the period estimated to be required to remove the ore. Fair market value is thus ascertained. From that point on, the computation of the deduction is similar to that described for cost depletion. ${ }^{63}$ The deduction ceases when the basis reaches zero.

Percentage Depletion. This method allows the recovery to the taxpayer, tax free, of a given percentage of the gross income from the de-

59. Stanton v. Baltic Mining Co., 240 U. S. 103 (1916); cf. Doyle v. Mitchell Bros. Co., 247 U. S. 179 (1918).

60. In Stanton v. Baltic Mining Co., 240 U. S. 103 (1916), the taxpayer's contention was that this allowance, limited to an arbitrary five per cent of the gross value of the mine's output for the year, was totally inadequate to compensate for the cost of the ore extracted.

61. INT. REv. CoDE §114(b) (1) (1939). The linking of tax bases for depletion and for gain (but not loss) on sale or other disposal, dates from the Revenue Act of 1924, 43 STAT. 270, §\$214(a) (8), 214(a) (9).

62. U. S. Treas. Reg. 111, Art. 29.23(m)-2.

63. Int. Rev. CODE $\S 114$ (b) (2) (1939). U. S. Treas. Reg. 111, Art. 29.23(m)-3, $-6,-7,-14$. 
posit upon the arbitrary assumption that the taxpayer has extracted the specified percentage from the total deposit during the year. Percentages differ, depending upon the mineral. ${ }^{64}$ The tax consequences of this method are at once distinguishable from those of cost and discovery, since under it the taxpayer may continue to deduct depletion after his cost or the fair market value of the deposit is recovered.

The Revenue Acts of 1913 and 1916 provided only for the cost method of computing depletion. ${ }^{65}$ The 1918 Act, however, allowed discovery depletion to minerals and oil and gas, retaining cost depletion as the basis for all other natural resources. ${ }^{\circ 6}$ This practice was followed in the $1921^{67}$ and $1924^{68}$ Acts.

Percentage depletion made its appearance first in the Revenue Act of 1926. Discovery depletion was limited to mines, and a new provision inserted providing for percentage depletion in the case of oil and gas wells. Cost depletion was continued for other natural resources. ${ }^{63}$ This procedure was continued in the Revenue Act of $1928 .{ }^{70}$

In the Revenue Act of 1932, percentage depletion was substituted for discovery depletion in the case of coal, metal mines, and sulphur; and producers of these resources required to make an election as to whether they would claim cost or percentage depletion. The election, once made, was binding on the taxpayer for subsequent years. ${ }^{71}$ These provisions remained unchanged in the Revenue Acts of $1934,{ }^{72} 1936,{ }^{73}$ and $1938,{ }^{74}$ and were carried over into the Internal Revenue Code. ${ }^{35}$

64. INT. REv. CoDE, §114(b) (4) (1939).

65. 38 Stat. 114, 167, 172, Revenue Act of 1913, $\S$ II B (individuals), II G(b) (corporations) ; 39 StAT. 756, Revenue Act of 1916, $\$ \$ 5$ (a) (individuals), 12(b) (corporations). The 1913 Act limited the deductions as to minerals to five per cent of the gross value of the mine's output.

66. 40 Stat. 1057, Revenue Act of 1918, $\S 214$ (a) (10) (individuals), 234(a) (9) (corporations). The deduction under the discovery depletion mathod was limited to the net income from the property computed without the depletion deduction.

67. 42 STat. 227, Revenue Act of 1921, $\$ \$ 214(3)$ (10) (individuals), 234(a) (9) (corporations). The deduction under the discovery depletion method was limited to the net income from the property computed without the depletion deduction.

68. 43 StAT. 253, Revenue Act of 1924, $\$ \$ 204$ (c), 204(a) (9) (individuals), 234(a) (8) (corporations). Deductions were limited to fifty per cent of the net income (computed without allowance for depletion) from the property upon which the discovery was made and were in no case to be less than if computed upon the cost method.

69. 44 STAT. 9, Revenue Act of 1926, $\$ 204$ (c) (1) (2).

70. 45 STAT. 791, Revenue Act of 1928, $\S 23(\mathrm{~A})(\mathrm{m}), 114(\mathrm{~b})$.

71. 47 Stat. 169, Revenue Act of 1932, $\S \S 23(\mathrm{f}),(\mathrm{m}), 114(\mathrm{~b})$. No election was requirred of producers of oil and gas.

72. 48 STAT. 680 , Revenue Act of $1934, \S \S 23(\mathrm{~m}),(\mathrm{n}), 114(\mathrm{~b})$.

73. 49 Stat. 1648, Revenue Act of 1936, $\$ 23(\mathrm{~m})$, (n), 114(b).

74. 52 Stat. 447 , Revenue Act of 1938, $\S \S 23(\mathrm{~m}),(\mathrm{n}), 114(\mathrm{~b})$.

75. INT. REv. CODE $\S 23(m),(n), 114(b)$ (1939). 
In the Revenue Act of $1942,{ }^{76}$ a group of non-metallic minerals ${ }^{77}$ were afforded percentage depletion, subject to the limitations applicable to metal mines; and in the Revenue Act of 1943, this group was expanded materially. ${ }^{78}$ In each case, percentage depletion was allowed in lieu of discovery depletion, ${ }^{70}$ and the change from discovery to percentage depletion was to be effective only for the duration of the war. ${ }^{80}$

Percentage depletion as a tax policy is the outgrowth of two factors. The first of these was the desire to eliminate the entanglements attendant upon the administration of both the cost and discovery methods of depletion. "Cost" involved considerations of development expense, cost of the land, and outlays recoverable through depreciation and expense deductions. "Fair market value," a concept which has always bred differences of opinion, presented insuperable difficulties in the case of ore deposits. For most minerals only the analytical appraisal method of valuation is available. This method involves an estimation in advance of prices and costs for many years into the future and is nothing more than an expensive guess. ${ }^{81}$ In addition to valuation difficulties, the determination of the recoverable content of the deposit is in most instances unreliable.

These sources of aggravation and their attendant administrative difficulties had long nettled both the Treasury and the taxpayer; and Con-

76. No changes were made in the Code provisions by the Revenue Acts of 1939, 1940, or 1941.

77. Section 145 of the Revenue Act of 1942, 56 STAT. 798, added fltorspar, ball and sagger clay, and rock asphalt to the list of natural resources entitled to percentage depletion deductions for income tax purposes. No election is required. Either cost or percentage may be used, whichever gives the greater deduction.

78. Section 124(a) of the Revenue Act of 1943 added flake graphite, vermuculite, potash, beryl, feldspar, mica, talc, lepidolite, spodumene, and barite to the list of non-metallic minerals afforded percentage depletion. Discovery depletion was consequently terminated.

79. Revenue Act of 1943, §124(b).

80. Revenue Act of $1943, \S 124(\mathrm{e})$. Section $124(\mathrm{c})$ of the new law adds to Internal Revenue Code section 114(b) (4) paragraph (B), which defines gross income from mining properties in respect of which percentage depletion is calculated. This term had formerly been left to the Treasury for definition. The new statute states that the term includes "not merely the extraction of ore" but, in addition, "the ordinary treatment processes normally applied by mine owners or operators in order to obtain the commercially marketable mineral product or products." Processes included in "the ordinary treatment processes" are set forth in the law for the various minerals. The new definition extends and makes specific the Treasury's definition of the term. U. S. Treas. Reg. 111, Art. 29.23(m) $-1(f)$.

81. A discussion of Haskold's formula, widely used in connection with mineral valuation arrived at by the analytical appraisal method, appears in 10 MERTENs, LAW OF FEDERAL INCONE TAXATION (1943) \&59.111. Some of the cases applying the formula are there collected. See U. S. Treas. Reg. 111, Art. $29.23(\mathrm{~m})-7$, where the opinion is expressed: "Valuation by analytical appraisal methods, such as the present value method, are not entitled to great weight, (1) if the value of a mineral deposit can be determined upon the basis of cost or replacement value, (2) if the knowledge of presence of the mineral has not 
gress in an effort to remove them ${ }^{82}$ resorted to percentage depletion. ${ }^{83}$ A second consideration prompting the adoption of the percentage method lay in its stimulating effect upon the search for new ore deposits. ${ }^{83}$

But the method has an inherent tax weakness. The continuation of the allowance of a tax deduction of a percentage of gross income varying from five per cent in the case of coal mines to twenty-three per cent in the case of sulphur mines long after the cost of the deposit has been recovered makes for facile administration and is well calculated to encourage explorations. ${ }^{85}$ But such excessive deductions distort the ore producer's tax liability beyond the normal limits of accuracy common to rule of thumb cases and result, of course, in a substantial loss of revenue.

The extension of percentage depletion to an enlarged group of nonmetallic minerals effected by the Revenue Act of 1943 was recommended as an incentive measure designed to bring output up to the level of the country's wartime needs. ${ }^{86}$ It is to remain in the law only for the duration of the war. ${ }^{87}$ The determination of whether or not such a temporary incentive practice, with its concomitant loss of revenue, is justified as a socially desirable solution ${ }^{88}$ to the present shortage of strategic materials, may best be made with a modicum of consideration for tax consequences.

greatly enhanced the value of the mineral property, (3) if the removal of the mineral does not materially reduce the value of the property from which it is talien, or (4) if the profits arising from the exploitation of the mineral deposit are wholly or in great part due to the manufacturing or marketing ability of the taxpayer or to extrinsic causes other than the possession of the mineral itself. If the fair market value must be ascertained as of a certain date, analytical appraisal methods will not be used if the fair market value can reasonably be determined by any other method."

82. Sen. Rep. No. 52, 69th Cong., 1st Sess. (1926) 17-18; H. R. Rep. No. 350, 69th Cong., 1st Sess. (1926) 31-32.

83. To the extent that the deduction for depletion computed under the percentage method is not to fall below that allowed had the deduction been computed under the cost method, the problem of valuation and recoverable content may still stall: the marginal producer.

84. Percentage depletion, moreover, treats alike all producers of the ore, regardless of discovery value or cost. This makes for equality of competitor's tax burdens.

85. Actually, this bounty is not as great as it may seem at first blush. The produser in many instances merely recoups capital expenditures from one plentiful depusit which were invested in many barren explorations.

86. See Hearings Before Conmittee on Finance on $H . R$. 3687, 78th Cong., 1st Sess. (1943) $363,527,839,926,968$.

87. Except for potash, the producers of which received permanent permission to use the percentage method for depletion deductions. Revenue Act of 1943, $\$ 124(\mathrm{c})$. The problem presented by the effect which the war years' deductions, based upon percentage depletion, will have upon the subsequent peacetime discovery or cost valuation bases may prove difficult of solution.

88. Other possible solutions: Governmentally subsidized explorations or governmental requisition of known deposits and facilities. 


\section{iII. The Treatment of Gain or Loss Upon the CutTing of TIMBer}

Since the Revenue Act of $1921,{ }^{80}$ Congress has recognized that more favorable tax treatment should be accorded to income received by the taxpayer from the increment in value of property disposed of during the year in a taxable transaction, called "capital gain," ${ }^{00}$ as distinguished from income received by the taxpayer from his personal service or as the harvest of his capital investments, called "ordinary income."

The principal argument against taxing capital gains as heavily as ordinary income is bottomed on the fact that capital gains often occur over several years, whereas ordinary income occurs only during the year in which the tax is imposed. If an income tax at surtax rates were levied upon capital gain in the year in which the gain is realized, a distorted and inequitable tax burden would be imposed.91 Capital gains, therefore, should be taxed in such manner that the tax approximates the burden which would have been imposed "if the gain had been realized in uniform annual amounts over the period during which the asset was held." 02 Such treatment tends to encourage the free flow of capital transactions and to prevent the stagnation of profit taking. ${ }^{03}$

In recognition of this principle, Congress by means of progressively more complicated formulae in each succeeding revenue law has provided special tax treatment for capital gains realized by individuals. In 1942

89. 42 Stax. 227, Revenue Act of 1921, 206.

90. This term as here used is not confined to the technical meanings ascribed to it in section 117 of the Internal Revenue Code.

91. This argument came from the Treasury Department. See Statement of Acting Secretary of the Treasury Regarding the Preliminary Report of Subcommittee of Committee on Ways and Means, Hearings before the Committec on Ways and Means on Retenne Revision, 1934, 73d Cong., 2d Sess. (1933) 4.

92. Supplemental Report on Capital Gains and Losses to Joint Committee on INTERNAL REVENUE TAXATION (1929) 2.

93. "The sale of farms, mineral properties and other capital assets is now seriously retarded by the fact that gains and profits earned over a series of years are under the present law taxed as a lump sum (and the amount of surtax greatly enhanced thereby) in the year in which the profit is realized. Many such sales, with their possible profit taking and consequent increase of the tax revenue, have been blocked by this feature of the present law. In order to permit such transactions to go forward without fear of a prohibitive tax, the proposed bill ... [provides] that where the net gain derived from the sale or other disposition of capital assets would, under the ordinary procedure, be subject to an income tax in excess of 15 per cent, the tax upon capital net gain shall be limited to that rate." H. R. REP. No. 350, 67th Cong., 1st Sess. (1921), pt. 1, 10, reprinted in 1939-1 Cum. BuLL, pt. 2, 168, 176. The bill as enacted provided for a tax equal to twelve and one-half per cent of the capital net gain. 42 Stax. 227, Revenue Act of 1921, $\$ 206$.

A statement similar to the one cited from the House Committee Report is found in SEN. Rep. No. 275, 67th Cong., 1st Sess. (1921), pt. 1, 13, reprinted in 1939-1 CuM. Bult., pt. 2,181, 189. It is there stated: "In Great Britain capital gain or loss is ignored in computing the net income. Section 206 takes an intermediate position between the extreme views embodied, respectively, in the present American and British laws." A discussion of the British law appears in Magirl, Taxable Incone (1936) 70 et seq. 
this special treatment, in more restricted fashion, was extended to corporations. ${ }^{94}$

As in the case of the "reorganization" sections, application of the special capital gains provision was circumscribed in each revenue act by a definition. Gain was to be subject to the favored treatment described in the statutes only if the property disposed of was a "capital asset." Therefore, it was necessary at the outset to determine whether or not the property involved in the transfer was within the meaning of this term.

The definitions of this term which have appeared in the various revenue laws have been extensive. By them the defined term included all classes of property not specifically excluded from the definitions. ${ }^{03}$ But from the first the definition has shut out stock in trade of the taxpayer and other property of a kind which would properly be included in the taxpayer's inventory. ${ }^{90}$ Later this exclusion was broadened to include "property held by the taxpayer primarily for sale in the course of his trade or business"; ${ }^{97}$ and, still later, it was modified to "property held by the taxpayer primarily for sale to customers in the ordinary course of his trade or business." 98 It was felt that property of the nature dealt with in the exclusion was subject to a "turn over" or "sell off" within the

94. 56 StAT. 798, 843, Revenue Act of 1942, $\$ 150$ (c), amending Is:T. REv. Cogs, $\$ 117$ (c) (1) (1939). Until the advent of heavy wartime tax levies, corporations paying a fixed or ungraduated rate of tax were little affected by the considerations which led to the capital gain provision in the earlier income tax laws.

95. "It will be noted that the definition includes all property, except as specifically: excluded." H. R. Rep. No. 704, 73d Cong., 2d Sess. (1934), 31, reprinted in 1939-1 Cus. BurL., pt. 2, 554, 577.

96. 42 STAT. 227, Revenue Act of $1921, \S 206$ (a) (6), and corresponding provisions in subsequent revenue acts.

97. 43 STAT. 253, Revenue Act of $1924, \S 208$ (a) (8). "The last part of the definition of capital assets is changed to remove any doubt as to whether property which is held primarily for resale constitutes a capital asset whether or not it is the type of property which under good accounting practice would be included in the inventory." $H$. R. REP. No. 179, 68th Cong., 1st Sess. (1924) 19, reprinted in 1939-1 Cuar. BuLL, pt. 2, 241, 255. A similar explanation was given by the Senate Finance Committec. SE:. REp. No. 398, 68th Cong., 1st Sess. (1924) 22, reprinted in 1939-1 Cuas. BuLn, pt. 2, 266, 281. Thus real estate, though not the proper subject of an inventory, may, nevertheless, be held by the taspayer for sale in his trade or business. Ehrman v. Commissioner, $120 \mathrm{~F}$. (2d) 607 (C. C. A. 9th, 1941) ; Snell v. Commissioner, 97 F. (2d) $\$ 91$ (C. C. A. 5th, 1938); Richards v. Commissioner, 81 F. (2d) 369 (C. C. A. 9th, 1936); Phipps v. Commissioner, 54 F. (2d) 469 (C. C. A. 2d, 1931).

98. 48 Stat. 680 , Revenue Act of $1934, \S 117$ (b). This slight revision was "to prevent tax avoidance," SEN. REP. No. 558, 73d Cong., 2d Sess. (1934) 12, reprinted in 1939-1 Cux. BuLI, pt 2, 586, 595, "making it impossible to contend that a stock speculator trading on his own account is not subject to the provisions of "section 117." Cosranesce CossartTtee Rep. No. 1385, 73d Cong., 2d Sess. (1934), reprinted in 1939-1 Cus. BuLl, pt. 2, 627,632 . The deductibility of losses on capital assets suffered by stock traders in a period of declining values was here in the minds of the Conference Committce. For a discussion of the capital gain and loss provision of the 1934 Act which severely limited deduction of capital losses, see Hendricks, Federal Income Tax: Capilal Gains and Losses (1935) 49 HaRv. L. Rev, 262. 
period of a year or less in most instances and, therefore, should be considered as giving rise to income realized within the taxable year subject to ordinary income tax rates.

It was the application of the "capital asset" definition to the disposal of growing timber which led to the special provision in the 1943 Act in favor of the timber industry. The definition had been applied with results varying according to the circumstances surrounding the removal of the timber.

A taxpayer who owns growing timber may harvest it himself, convert it into lumber, and dispose of the lumber to his customers. Under such circumstances there would appear to be no question but that under prior law the transaction was within the exclusion from the definition dealing with property held for resale to customers, and profit on the operation was taxed as an ordinary gain. On the other hand, the taxpayer who sold his growing timber en bloc for a lump sum dealt with a "capital asset" and was entitled to treat excess of selling price over cost as a capital gain, subject to favored treatment.

Yet a third method of disposition exists. The taxpayer may dispose of his growing timber under a so-called "cutting" contract, wherein the price to be paid to him by the purchaser is reckoned at so much per thousand feet of timber cut, the owner retaining an economic interest in the timber until it is paid for. Under such circumstances, can it be said that the owner of the timber is engaged in "a trade or business" so that the timber is held "primarily for sale to customers in the ordinary course of his trade or business?" 90

99. The test to be applied was thus stated by the Board of Tax Appeals at an carly date: Did the contract of disposal, considering all its terms, effect a sale of the entire standing timber in such a way as to constitute the purchasers agents of the seller, so that through them the seller was engaged vicariously in lumbering operations? John W. Blodgett, 13 B. T. A. 1388,1389 (1928).

100. Commissioner v. Boeing, 106 F. (2d) 305 (C. C. A. 9th, 1939), ccrt. denied, 308 U. S. 619 (1939). The taxpayer inherited certain timber lands and acqutired others, all of which were held for investment purposes. The contracts of disposal provided that the logging company would construct railroads, camps, and other necessary structures at its expense and cut $600,000,000$ feet of logs each year during the term of the contract. It was further provided that the logging company should pay all taxes and assessments levied against either land or timber during the period of the contract. All logs clit were to be removed and sold by the purchaser at the current market price, the moneys received to be divided one-third to the taxpayer for his interest in the logs, including stumpage and stumpage rights, two-thirds to the logging company in payment for its services. In one of the contracts it was provided that title to the logs and other timber products to be cut or removed from the land should remain in the owner at all times until sold, purchasers of the timber from the logging company being billed separately for the amount due the timber owners and remittance made directly to them. It was further provided that the work of cutting and removing the timber should be completed on a date set in the agreement; otherwise, the logging company should purchase the timber remaining on the lands at current market prices, to be paid within sixty days, and remove it within ten years. 
When this question reached the courts, it was answered in the affirmative. ${ }^{100}$ The facts necessary to create the status of one engaged in a "trade or business" were viewed as revolving largely around the frequency or continuity of the transaction claimed to result in a business status. ${ }^{101}$ The fact that the taxpayer's contractual negotiations were motivated by a desire to liquidate his investment in the timber or that independent contractors were engaged to remove and market it was held not to be decisive. ${ }^{102}$

101. Commissioner v. Boeing; 106 F. (2d) 305,309 (C. C. A. 9th, 1939), ecrt. deried, 30 U. S. 619 (1939) ; of. Mfiller v. Commissioner, 102 F. (2d) 476,479 (C. C. A. 9 th. 1939) ; Welch v. Solomon, 99 F (2d) 41, 44 (C. C. A. 9th, 1938) ; Richards v. Commissioner, 81 F. (2d) 369, 373 (C. C. A. 9th, 1936); Phipps v. Commissioner, 34 F. (2d) 469 (C. C. A. 2d, 1931).

102. Commissioner v. Boeing, 105 F. (2d) 305, 309 (C. C. A. 9th, 1939), cert. dcnicd, 308 U. S. 619 (1939) ; cf. Richards v. Commissioner, 81 F. (2d) 369, 373 (C. C. A. 9th, 1936). In United States v. Robinson, 129 F. (2d) 297 (C. C. A. 5th, 1942), the contracts provided for the sale of all the merchantable pine and hardwood timber eight inches and over at $\$ 4.50$ and $\$ 6.50$ per thousand feet, with provisions for an incrense if the market price increased a certain amount. The quantity of timber sold was fixed by agreed estimates, and payment made in monthly installments in advance of cutting on the basis of these estimates regardless of the amount of timber actually cut, it being agreed that an average of at least 1,250,000 feet of timber would be cut each month. Thus any growth or loss in the timber subsequent to the making of the contracts and before it was cut, was the gain or loss of the purchaser. Interest was paid on the monthly installments after due date. The contracts provided that the purchaser would pay seventy-five per cent of all tawes accruing on the lands covered, this apparently being the estinuted proportion of the entire value of the land allotted to the timber. The contracts granted the purchaser certain "free time" within which to cut and remove the timber and an additional period of time when needed upon payment of a charge of fifteen cents per acre. It was held that this contractual arrangement constituted the disposal of a capital asset.

In Estate of M. M. Stark, 45 B. T. A. 882 (1941), the purchaser aciuired the esclusive right to "turpentine" and to cut and remove all the merchantable pine timber ten inches or more in diameter at the stump, for which he agreed to pay the taxpayer \$5 per thousand feet and the further sum of twenty-five per cent of the average selling price in excess of $\$ 13.50$ per thousand feet. The $\$ 6$ payment was to be made monthly for the timber cut the preceding month and the twenty-five per cent payment was to be made semi-annually. The timber was to be scaled at the mill at the joint expense of purchaser and seller. The purchaser was to build modern sawmill equipment of a certain capscity and other facilities for handling the timber, and cut not less than $4,000,000$, or more than $75,000,000$, feet of timber annually. If market conditions were such that the lumber would be sold at a loss to the purchaser, operations might be temporarily suspended. The timber was to be sold in a manner customary to the conduct of the industry. The purchaser was to organize a corporation to operate the business to which the purchaser's interest in the contract was to be assigned. The corporation's stock was to be subseribed for in eash by the purchaser and others whom he might procure, and the corporation's net profits paid out as dividends to stockholders until the net earnings equalled the total cost of the fixcd investment. Thereupon, the stock was to be recalled and reissued, fully paid up, one-half to purchasers and one-half to sellers. Voting control of the company, however, was to remain in the purchasers. It was held that the taxpayers were not engaged in the trade or business of selling timber and that the profits from the sale of timber under these contracts were realized as capital gains. 
It may be noted that under all three procedures outlined, cutting and processing by the taxpayer, sale en bloc, or cutting contract, the income was realized by the taxpayer from the same basic economic source, the appreciation in value of the growing timber; yet the tax consequence in the first and third situation could well be three- or fourfold greater than that in the second.

A desire on the part of Congress to relieve against the unequal treatment allotted forest owners by this interpretation of "capital asset," led to the accordance of capital gain privileges to timber owners in those situations which had formerly produced ordinary income. ${ }^{103}$ This change was effected by section 127 of the Revenue Act of 1943, which added subsection (k) to section 117 , of the Internal Revenue Code.

New section $117(\mathrm{k})$ is divided into two paragraphs. Under paragraph (1) it is provided that any taxpayer who owns timber or has a contract right to cut timber may elect ${ }^{104}$ to count the profit upon its harvest for process and sale in his business as a capital gain, upon which the rate of tax cannot exceed twenty-five per cent, ${ }^{105}$ provided he has owned the timber for more than six months prior to the beginning of the year.

103. Sen. Rep. No. 627, 78th Cong., 1st Sess. (1943) 57. It was also urged before the Ways and Means and Finance Committees that existing law influenced selling and cutting policies of timber owners in a way adverse to the maintenance of forest resources. Hearings Before Connmittee on Ways and Means on Revente Revision of 1943, 78th Cong., 1st Sess. (1943) 800, 811-14, 824, 833-34; Hearings Before Comnittec on Finance on H. R. 3687, 78th Cong., 1st Sess. (1943) 664-68. But the effect of the law on forestry is difficult to discern. It may be conceded that the pre-1944 system of taxation drives timber owners to sell out entirely, taking capital gains, but it does not seem reasonable to assume that new owners were any less experienced or less interested in cstablishing sound cutting methods. Moreover, under the doctrine of United States v. Robinson and Estate of $M . M$. Stark, discussed supra note 102, timber could be sold on a stumpage basis, which would insure a fair price to the owner and enable him to control the size and methods of cutting and to eliminate destructive or wasteful logging methods.

More calculated to induce desirable silviculture was the requested provision cnabling timber owners to capitalize or deduct, at their option, expenditures for planting, thinning, or pruning of timber, for trails, roads, telephone lines, fire lines, lookout stations, or similar expenditures appropriate for the protection of timber. Hearings Before Commiltec ant Ways and Means on Revenue Revision of 1943, 78th Cong., 1st Sess. (1943) 797; Hcarings Before Committee on Finance on H. R. 3687, 78th Cong., 1st Sess. (1943) 797-98, 805-06. The option given to the taxpayer of writing off these expenditures either as expenses or capital investments, would have insured the timber owner who had no income from his forests during the growth period a tax benefit from annual conservation expenditures, since he could add them to his capital base, whereas without such a provision he would be forced to use them as a deduction devoid of tax benefit for lack of offsetting income. The requested change was not adopted.

104. Of course, Congress could not force the payment of tax upon the increase in value of a tree when it is cut by the owner. It could not be said that income was "realized." See page 476 supra.

105. INT. REv. CODE $\S 117$ (c) (1939). 
If a loss should occur, it is deductible in full from ordinary income. ${ }^{103}$ Under paragraph (2) it is provided that the disposal of timber held for more than six months under any form of "cutting" contract by which the owner retains an economic interest in the timber shall be considered as a sale of the timber, gain or loss to be recognized as capital gain or ordinary loss in an amount equal to the difference between the depletion basis (ordinarily cost less allowable depletion) of the timber and the amount received for it. ${ }^{107}$ The discrimination which formerly existed between the disposal of timber under circumstances covered by the new law and a sale en bloc is thus effectively eliminated.

Under paragraph (1) gain is to be recognized in an amount equal to the difference between the depletion basis of the timber and its fair market value on the first day of the taxable year in which it is cut. ${ }^{103}$ The fair market value figure shall thereafter be considered as the cost of the cut timber to the taxpayer for all purposes for which cost is a necessary factor. An election must apply to all timber owned by the taxpayer or in which he has a cutting right and shall be binding upon him for all subsequent years, unless the Commissioner of Internal Revenue, upon a showing of undue hardship, permits a revocation. After revocation, further election is precluded in the absence of the Commissioner's consent.

The application of these provisions to several hypothetical situations will serve to demonstrate their operation:

106. Revenue Act of $1943, \S 127$ (b). The deduction is actually accomplished by scetion $117(\mathrm{j})$. By this section, profits from the disposal of imvoluntarily cunverted eapital assets; property of a character which is subject to the allowance fur depreciation provided in section 23(1) of the Internal Revenue Code, used in the trade or business of the taxpayer and held for more than six months; and real property used in the trade or business of the taxpayer, held for more than six months, provided neither is of a lind of property includible in the taxpayer's inventory or held for resale to customers, are tased as capital gains, loss deducted as ordinary loss. Section 127(b) of the Revenue Act of 1943 adds to section $117(\mathrm{j})$ of the Code, timber, with respect to which the new subsection $117(\mathrm{l})$ is made applicable.

107. Section 127 (c) of the Revenue Act of 1943 inserts a provision having the effect of section $117(\mathrm{k})(2)$ in the revenue laws applicable to all taxab!e years since the advent of modern federal income tax legislation, that is, Jarch 1, 1913. Since paragraph (2) of section $117(k)$ is linked to Code section $117(j)$, added by 56 Star. 798, 846, Revenue Act of $1942, \S 151$, for years to which section $117(j)$ applies (those commencing after December 31, 1941), the gain or loss treatment provided retroactively fur "cutting" contract situations will have to be considered together with gains or losses frum sales or exchanges of real estate and depreciable property used in the taspayer's trade ur business and involuntary conversions of capital assets all held for more than six munths. If aggregate gain exceeds aggregate loss, all gains and all losses will be treatcd as capital ones. If, however, aggregate losses exceed aggregate gains, all will be ordinary. Fur years ty which section 117 (j) does not apply (years commencing prior to December 31, 1941), ordinary capital gain or loss treatment is afforded. Retrozetivity was granted fur paragraph (2) of section $117(k)$ in response to the following plea:

"With respect to paragraph (2) the following points should be noted: 


\section{A}

Assume that $A$ owns $1,000,000$ feet of growing timber acquired on January 1,1943, which bears a depletion basis in his hands of $\$ 3$ per ,thousand feet. On January 1, 1944, this timber has a fair market value of $\$ 6$ per thousand feet. During $1944 A$ cuts and processes 500,000 feet, seiling it to customers in the ordinary course of his lumber business. There is a capital gain of $\$ 3$ per thousand feet on the timber cut, which is taxable under the capital gain provisions of the Internal Revenue Code. ${ }^{109}$

The capital gain ( $\$ 3$ ) is then added to the depletion basis ( $\$ 3$ ), creating a new basis of $\$ 6$ for the cut timber, which is to be used in all computations in which cost is a factor. The basis of the uncut 500,000 feet remains at $\$ 3$.

If $A$ sold the 500,000 feet cut during 1944 at $\$ 10$ per thousand and costs of production (except depletion basis) amounted to $\$ 3$ per thou-

"(a) For many years the owner of timber, whether he sold it en bloc or whether he sold it under a cutting contract or under some similar form of contract by virtue of which he retained an economic or investment interest in stch timber, has been accorded capital gain treatment as to the difference between the amount received and the adjusted depletion basis of such timber. Recently the Bureau of Internal Revenue has proposed a new treatment taking away the right to capital gain treatment in such cases on the theory that the owner has retained an economic interest in such timber. The purpose of this paragraph is to provide by law for the continuation of the rule followed for many years, and thits to give to the owners of timber who have sold same under such contracts practically the same treatment as it provided for under paragraph (k) (1).

"(b) Inasmuch as the Bureau proposes to apply its new theory (mentioned above) retroactively in the case of all years not closed by the statute of limitations, it seems necessary to give this paragraph retroactive effect." Hearings Before Committee on Ways and Means on Revenue Revision of 1943, 78th Cong., 1st Sess. (1943) 805. See also statement of Lovell H. Parker, id. at $795,803$.

The recent rulings of the Bureau of Internal Revenue referred to were unpublished instructions issued to field agents in January, 1943. But see Commissioner v. Boeing, 106 F. (2d) 305,309 (C. C. A. 9th, 1939), cert. denied, 308 U. S. 619 (1939). The Bureat's policy was similar to its view of oil and gas leasing transactions in situations involving principles common to the "cutting" contract case. See G. C. M. 22730, 1941-1 Cur. BuLL. 214.

108. "To avoid a multiplicity of valuations during the taxable year, the fair market value of the timber on the first day of such year is made controlling." Hearings Beforc Committee on Ways and Means on Revenue Revision of 1943, 78th Cong., 1st Sess. (1943) 805.

109. For simplicity it is assumed that this is the only taxable operation engaged in by the taxpayer. If he should be engaged in cutting timber from several tracts, some of which had lower fair market values than depletion bases, gains and losses wottl have to be marshalled, and determined under section $117(j)$ of the Internal Revenue Code. See notes 105 and 106 supra. The examples given here closely parallel some of those appearing in the reports of the committee hearings on the bill. 
sand, there would be an ordinary gain of $\$ 1$ per thousand feet ( $\$ 6$ plus $\$ 3$ subtracted from $\$ 10$ ), taxable at ordinary surtax rates.

If, in the above example, the fair market value of the cut timber on January 1, 1944, had been $\$ 2$ per thousand feet, there would be an ordinary loss of $\$ 1$ per thousand feet, fully deductible from ordinary incume. The basis for computing gain or loss ${ }^{110}$ on the sale of the lumber processed from the timber would be $\$ 2$. The basis for the uncut timber would remain at $\$ 3$.

\section{$\mathrm{B}$}

Assume that, pursuant to a cutting contract with $B$ made on January 1, 1943, $A$ has the right to cut all the merchantable timber of the diameter of eight inches or more at the stump from $B$ 's lands, market the timber, and pay $B$ from the proceeds $\$ 4$ per thousand feet for the logs removed, title to the timber to remain in $B$ until sold. During $1944 A$ cuts 500,000 feet of timber which had a fair market value of $\$ 6$ per thousand on January 1,1944 . There is a capital gain to $A$ of $\$ 2$ per thousand fect, and his new basis for the lumber to be used in reckoning profit in his business is $\$ 6$.

If the timber cut had had a fair market value on January 1, 1944, of $\$ 3$, there would have been a loss to $A$, fully deductible, of $\$ 1$ per thousand feet.

$B$ 's gain or loss likewise is capital or ordinary, being computed by subtracting his depletion basis from the price per thousand feet paid to him by $A(\$ 4)$. There is no change in the basis of the uncut timber covered by the contract. ${ }^{111}$

110. Taxable at ordinary surtax rates or deductible in full frum ordinary incume.

111. The following example is taken from Hcarings Bcfore Conmitte wh l"ays and Means on Recenue Revision of 1943, 78th Cong., 1st Sess. (1943) 807, and demonstrates the change effected in existing law. It applies to a situation wherein the timber civner cuts, processes, and markets his own timber.

"Price received for 1,000 feet of lumber sold $\ldots \ldots \ldots \ldots \ldots \ldots \ldots \ldots \ldots . \quad \$ 25$

All costs of production excepting depletion $\ldots \ldots \ldots \ldots \ldots \ldots \ldots \ldots \ldots .18$

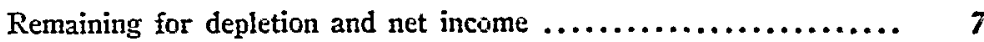

Depletion, adjusted basis (on timber held by the taxpayer for perhaps twenty years, or perhaps grown on the land of the taxpayer while in his possession) $\ldots \ldots \ldots \ldots \ldots \ldots \ldots \ldots \ldots \ldots \ldots \ldots \ldots \ldots \ldots \ldots, \quad 1$

Net income under present law ..........................

Capital gain on timber cut (current fair market value of $\$ 3$ less adjust-

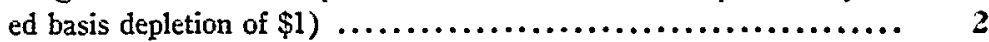

Net income realized 'within the year' through the process of converting standing trees to lumber and selling the lumber ......... \&

"Under the present law the $\$ 6$ net income would be given urdinary tax treatment. Under the proposed amendment the $\$ 4$ of net income frum the process of conversion would be given the ordinary tax treatment, and the $\$ 2$ of capital gain would be taxed as a capital gain." 
It has already been pointed out that the new classification of income from the disposal of growing timber effects uniform treatment of income received from the same basic economic sources, while before, tax consequences varied with technicalities surrounding the removal of the timber. In this respect it may be said that the new provisions leave policies for the handling of timber land to be determined by the requirements of the forest industry, free from the dictates of tax pressures. But a critique of the new law cannot stop with this observation. The issue is whether or not capital gain treatment has been unjustly extended to a situation rightfully to be treated as one producing ordinary income. Is the gain upon the liquidation of growing timber truly a capital gain, or should timber be thought of as a growing crop producing annual income? ${ }^{112}$

In behalf of the new law it may be pointed out that since gain accrues over a long period of time, opportunity is afforded for the play of extraneous economic conditions upon values. Concretely put, as a result of the long period during which timber value is created, that value in part may be due to such circumstances as the decline in value of the dollar ${ }^{113}$ and not entirely to a change in intrinsic worth of the logs through growth.

Moreover, the product of this long growth can be harvested economically only by a concentrated cutting of all merchantable timber in the area served by the logger's facilities. Thus value which took years to accrue is harvested in a short period, often a year or less. The yield of a timber plot, accruing in infrequent but concentrated bunches, has the disadvantage common to irregular income (as contrasted with periodic income of one-season crops) which results from steeply graduated surtax rates.

Affording capital gain treatment to the cutting of growing timber neutralizes these adverse tax consequences and their attendant tendency to militate against the incentive to maintenance of forest lands by private capital. But in correcting inequities Congress has extended capital gain treatment for the first time to an operation conjunctive with the taxpayer's trade or business. Expansion of this novel principle might well be urged by other industries upon the ground of inequalities as appealing

112. It should be noted that, unlike the extension of percentage depletion to minerals theretofore denied its use, Revenue Act of 1943, $\$ 124$ (see page 471 stupra), and the relief from excess profits taxes upon "exempt excess output" of the mineral, timber, and gas industries, Revenue Act of $1943, \S 209$ (see page 485 infra), the provisions of section 127 of the 1943 Act affording capital gain treatment upon the cutting of timber are a permanent feature of federal income tax legislation. This section cannot, therefore, be judged as one designed to relieve a shortage of critical materials situation developed by the war emergency.

113. Since the enactment of the 1913 income tax law, the purchasing power of the dollar has substantially decreased, principally because of the reduction of the dollar's gold content in 1933, and two world wars. 
as those which fostered the timber amendment. ${ }^{114} \mathrm{~A}$ wiser solution to the problem created by the adverse features of prior law should be devised.

\section{Excess Profits Tax Exemption for Natural Gas Companies}

Two years after the enactment of present excess profits tax legislation Congress was persuaded in the Revenue Act of 1942 to afford special excess profits tax treatment to the mining and timber industries. ${ }^{116}$ The War Production Board and the Office of Price Administration, ${ }^{110}$ in an endeavor to stimulate production, were offering premium prices above ceiling prices for production of certain metals in excess of specified established quotas. It was felt that should these bonus payments be subjected to the ninety per cent excess profits tax, much of their stimulating effect would be lost, ${ }^{117}$ and, accordingly, complete exemption from excess profits taxes was granted to them. Premium prices paid for timber production in excess of quotas were also exempted.118

114. For example, the extraction industries. Brick manufacturers may contend for capital gain treatment upon the extraction of clay from clay deposits, etc.

115. 56 Stat. 798, 904, Revenue Act of 1942, $\$ 209$.

116. 7 FED. REg. 4253 (1943).

117. H. R. REP. No. 2333, 77th Cong., 2d Sess. (1942) 149.

118. Section 209(a) of the Revenue Act of 1942, 56 SrAT. 798, 904, amended Isis. Rev. CODE $\$ 711$ (a) (1) (excess profits income credit) by adding subparagraph (I) thereto and INT. REv. CoDE $\$ 711$ (a) (2) (excess profits invested capital credit) by adding subparagraph $(\mathrm{K})$ thereto, which excluded from the taxpayer's excess profits tax net income bonus income from mineral and timber properties. The exclusion, in the computation of excess profits net income, of bonus income received for increased production of timber appeared in the bill between the time of its report by the Senste Finance Committee and the time it was agreed to by the Conference Committee. See H. R. Co:renge:ce REP. No. 2586, 77th Cong., 2d Sess. (1942) 27-28. As yet no premium prices have been authorized by the Office of Price Administration with respect to timber. The minerals affected vere defined by section 209 (c), which enacted new Ixr. REv. Cone $\S 735(c)$, to be those subject to depletion allowances, that is, ores of the metals, coal, and a host of non-metallic substances such as abrasives, asbestos, asphaltum, barytes, borax, building stone, cement rock, clay, crushed stone, feldspar, fluorspar, fullers' earth, graphite, gravel, gypsum, limestone, magnesite, marl, mica, mineral pigments, peat, potash, precious stones, reiractories, rock phosphate, salt, sand, silica, slate, soapstone, soda, sulphur, and tale. The exempt bonus income shall not exceed the net income (computed with the allowance for depletion) attributable to the output in excess of the quota. See SEN. Kep. No. 1631, 77th Cong., 2d Sess. (1942) 187. By Pub. L. No. 172, 7Sth Cong., 1st Sess. (approved Oet. 26, 1943), Congress added to the definition a mineral product extracted or recovered from mine tailings by a corporation which owns no economic interest in the mineral property from which the ore containing such tailings was mined, but such amount shall not exced the net income attributable to the output in excess of such quota. The amendment was to be effective as if part of section 209 of the Revenue Act of 1942 on the date of its enactment. 
But the exemption did not stop with bonus payments. Partial exemption from excess profits taxes was also accorded to the net income of these industries attributable to their excessive output as compared with their normal output. Normal output was determined to be the average output during the taxable years beginning after December 31, 1935, and not beginning after December 31,1939, the same years specified to be used in ascertaining the excess profits tax credit based on income. This partial exemption, in the case of mineral property other than coal and iron, was based upon the normal profit, computed with reference to the base years, received upon' the excessive output, and was limited to varying percentages of the normal profits attributable to the excessive output, depending upon the per cent which the excess output was of the sum of the estimated reserve or balance left in the deposit at the end of the taxable year. Thus if this percentum was fifty or more, all of the normal profit attributable to the excessive output was exempted from excess profits tax, while if the percentum was but five, only one-fifth of the normal profit attributable to the excessive output was exempt. Relief

119. INT. REv. CODE $\$ 713(b)(1)(A)$.

120. INT. REv. CODE $\$ \$ 735$ (a), 735(b), added by section 209(c) of the Revenue $\Lambda$ ct of 1942. SEN. REP. No. 1631, 77th Cong., 2d Sess. (1942) 188-89, gives the following illustration of this exemption:

"Assume that for each of three nonferrous metal mines, the normal output during the base period was 100,000 tons, and that the net income with respect to the minerals recovered was $\$ 100,000$, resulting in a normal unit profit of $\$ 1$ per ton. During the taxable year, each of the mines produced 210,000 tons at a profit of $\$ 1.40$ per ton, producing net income from such minerals of $\$ 294,000$. At the beginning of the year, the reserves of mine $A$ were 300,000 tons, of mine $B$ were $1,000,000$ tons, and of mine $C$ were $2,000,000$ tons. The adjusted excess profits net income for each mine would be computed as follows:

\begin{tabular}{|c|c|c|c|}
\hline & Mine A & Mine B & Mine C \\
\hline 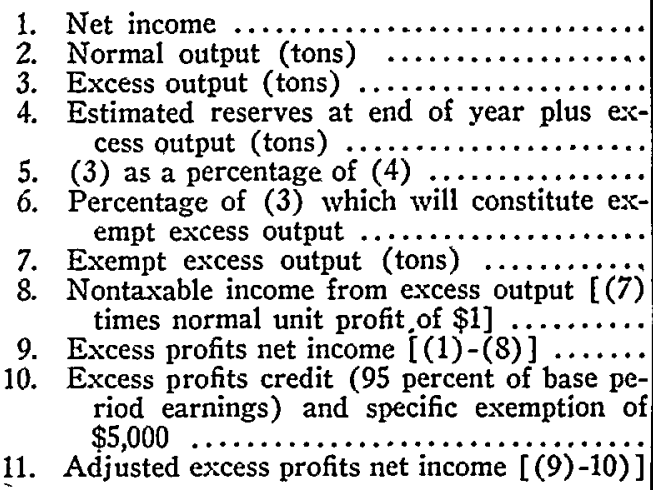 & $\begin{array}{r}200,000 \\
55.0 \\
100 \\
110,000 \\
\$ 110,000 \\
\$ 184,000\end{array}$ & $\begin{array}{r}900,000 \\
12.2 \\
\\
30 \\
33,000 \\
\\
\$ 33,000 \\
\$ 261,000\end{array}$ & $\begin{array}{r}\$ 294,000 \\
100,000 \\
110,000 \\
1,900,000 \\
5.8 \\
20 \\
22,000 \\
\\
\$ 22,000 \\
\$ 272,000\end{array}$ \\
\hline
\end{tabular}

The nontaxable income from exempt excess output, however, shall not exceed the net income, computed with the allowance for depletion, attributable to the excess output for the year. INT. REv. CODE $\$ 735$ (b) (1). 
was thereby made to depend upon the rapidity with which the deposit was being depleted. ${ }^{12 i n}$

The exemption in the case of timber properties was to be limited to one-half of the current year net incomi attributable to the increased output as compared to the base period output. ${ }^{121}$ while the exemption in the case of coal and iron properties was to be linited in either the manner applicable to minerals or timber, at the taxpayer's election. ${ }^{122}$ The chief distinction between that portion of the new law providing for exemption of the normal profit received upon the increased output and that portion of the new law providing for exemption of one-half the net income for the current year attributable to increased output is that the first provision deals favorably with companies which made a profit during the base period, but would grant no relief to companies which had a net loss during the base period. Moreover, the second method of affording the exemption is in no wise geared to the rate of exhaustion of the property.

If the income attributable to the excessive output of either of the classes of properties mentioned includes bonus payments, the taxpayer may elect to receive the benefits of nontaxable income from exempt excess output or of nontaxable bonus income with respect to that portion of the excess output in excess of the taxpayer's quota. ${ }^{123}$ The relief

121. INT. Rev. CODE $\$ 735$ (b) (3). added by 50 St.st. 798, 904, Revenue Act of $1942, \$ 209$ (c). This exemption may be illustrated hy the fullowing example clus gly paralleled in the House Committee Report: Assume the normal net incume of a timber block during the base period was 10,000,000 feet of lumber and the average nut insome from the property was $\$ 5,000,000$. Assume the output for the tasable year ending December 31, 1942, is 19,000,000 board feet, producing a net ineome, at a profit of $\$ 1.00$ par thousand board feet, of $\$ 19,000$. The excess profits tax of the timber bluel would lie reduced by this section by $\$ 4,050$ as follows:

(1) Taxable year net income ............................ \$19,000

(2) Taxable year output (thousand feet) $\ldots \ldots \ldots \ldots \ldots \ldots \ldots \ldots \ldots \ldots, 19,000$

(3) Normal output (thousand feet) $\ldots \ldots \ldots \ldots \ldots \ldots \ldots \ldots \ldots \ldots \ldots \ldots . .6 .10,000$

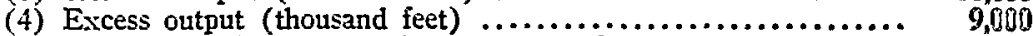

(5) Profit per unit of production (thousand feet) $\ldots . . . \ldots \ldots \ldots \ldots . . . \%$

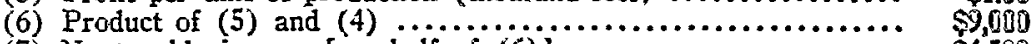

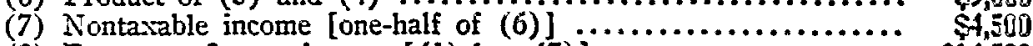

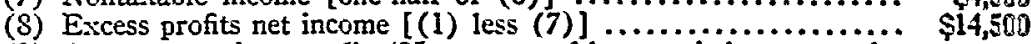

(9) Average earnings credit ( 95 per cent of base period average plus

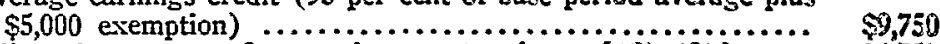

(10) Adjusted excess profits net income (or loss) $[(\$)-(9)] \ldots \ldots$.... $\$ 4,750$

(11) Excess profits tax at 90 per cent without the benefit of section $735 \quad \$ 8,325$

(12) Excess profits tax at 90 per cent with the benefit of sectiun $735 . . \quad \$ 4,275$

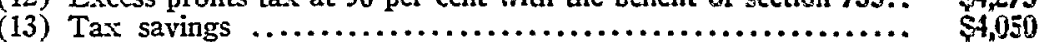

122. INTr. Rev. Cone $\$ 735$ (b) (2), added by 56 STAT. 798, 904, Revente Act of 1942, $\S 209(\mathrm{c})$.

123. INt. Rev. Cone $\$ 735$ (d), enacted by 56 Stat. 798,904 , Revenus let wi 1942, $\$ 209$ (c). Thus if in the illustration, given in note $120 \mathrm{supra}$, a quuta of 100,000 tuns had been established for each mine, and the current profit had included a bunus price of $\leqslant .14$ per ton, since output in excess of the quota is 110,000 tons, nuntasable bunus incume wuld amount to $\$ 14,000$. Whereas mine $A$ would elect to retain the benefits of the exclusion for nontaxable income from exempt excess output, mines $B$ and $c^{2}$ would elect to receive 
afforded by this provision to nontaxable bonus income was made retro: active to taxable years commencing after December 31, 1940.124

These exemptions were enacted because the outputs of the industries affected were limited to the amount of the reserve in their mineral deposits or timber properties. If these reserves were extracted over a period of years, the total amount of taxable excess profits would be materially less than if the extraction were bunched into a few years. Since concentration of output resulted from the demands of the national emergency rather than from the volition of the industries, it was argued that fairness demanded that the tax on the excess profits be partially remitted. ${ }^{12}$ The problem was not common to industries which did not have depletable resources, since their future production was not curtailed by exces- sive output. ${ }^{126}$

These same considerations were urged upon Congress in 1943 as grounds for the extension of these exemptions to the natural gas industry. ${ }^{127}$ In addition, it was argued that since natural gas can only be transported to markets through pipe lines ${ }^{128}$ provided in every case by the industry itself, tremendous investments in transportation facilities would become worthless during the period of excess profit taxation. Profits which under normal conditions would have gone to amortize the cost of the pipe lines over a period of years would be drained off in taxes with the bunching of output into a few taxable years subject to excess profits taxes. When deposits were exhausted, companies would be left with useless unpaid for pipe lines and little capital to explore new fields. ${ }^{120}$

Congress was won over ${ }^{130}$ by these arguments, and relief similar to

the benefits of a $\$ 44,000$ exclusion for nontaxable bonus income instead of an exćlusion for nontaxable income from exempt excess output which, in the case of mine $B$, was $\$ 33,000$, and, in the case of mine $C$, was $\$ 22,000$. See Sen. Rep. No. 1631, 77th Cong, 2d Sess. (1942) 189.

124. Int. Rev. Code $\S 735$ (d), enacted by 56 Stat. 798, 904, Revenue Act of 1942, $\S 209$ (c).

125. H. R. REp. No. 2333, 77th Cong., 2d 'Sess. (1942) 149. See Hearings Before Committee on Ways and Means on Revemue Revision of 1943, 78th Cong., 1st Sess. (1943) 722-23; Hearings Before Committee on Finance on $H$. R. 3687, 78th Cong., 1st Sess. (1943) 190.

126. H. R. REP. No. 2333, 77th Cong., 2d Sess. (1942) 149.

127. The natural gas industry is subject to state regulation, and as yet has received no "bonus" income. Nonregulated gas prices, that is, gas sold in the field or gas sold to industrial consumers in interstate commerce, are limited by the Office of Price Administration pursuant to the Emergency Price Control Act. 7 FED. REG. 14616 (1943).

128. In this respect it is unique among natural resources. Cf. President's Veto Message, N. Y. Times, Feb. 23, 1944, p. 1, col. 1, If D.

129. Hearings Before Committee on Ways and Means on Revente Revision of 1943, 78th Cong., 1st Sess. (1943) 719-20; Hearings Before Committee on Finance on H. R. 3687, 78th Cong., 1st Sess. (1943) 182-83.

130. The natural gas industry requested: (a) relief based directly upon increased output without relation to recoverable reserves; (b) optional relief similar to that accorded 
that granted by the 1942 Act with respect to coal mining, iron mining, and timber properties was extended to natural gas companies. ${ }^{131}$ Influenced by the pipe line transportation argument, Congress provided that natural gas nontaxable income from exempt excess output was to be computed not only with respect to net income derived from withdrawal of natural gas, but also to net income derived from its storage and transportation by pipe line. ${ }^{132}$ Excluded from this computation, however, was all income attributable to the distribution of the gas. ${ }^{133}$

The excessive output of the industry was to be determined in a manner identical to that employed in the case of minerals and timber, and the nontaxable income from this excessive output in the manner hitherto employed for timber, that is, it was to be an amount equal to one-half of the current year net income attributable to the excess output. ${ }^{138}$

Since the earnings of gas companies were subject to regulation during the base period, profits of the industry were small compared with those of nonregulated businesses. ${ }^{135}$ Therefore, confining computation of the nontaxable income from exempt excess output to a method based upon net income attributable to the excess output, excluding the method based upon normal profit from the increased output, ${ }^{150}$ seems entirely in

coal and iron mines, INT. REv. CODE $\$ 735$ (b)(2), but without restriction to onehalf the yearly income from the excess output; (c) retroactivity to tasable years commencing after December 31, 1941. Hearings Before Commillec on I"ays and Wrons, 78th Cong., 2d Sess. (1943) 725. The first and third requests were granted. Revenue Act of $1943, \S 208$.

131. Revenue Act of $1943, \S 208$. Also included within the excmptions by this scetion: lessors and sublessors of mineral properties, timber blocks; new soal and iron mines and timber blocks not in operation during the "base" period. Revenue Act of $1943, \$ 20 \$(c)$, which added new paragraph 735(b) (4) to the Internal Revenue Code.

132. To the extent that relief granted to natural gas companies includes income attributable to the storage and transportation of natural gas, it represents a more liberal exemption than that afforded coal mining, iron mining, and timber properties.

133. Revenue Act of 1943, $\S 20$ (b), adding section 735(a) (5) to the Internal Revenue Code. Relief is available only if the whole or any part of the company's natural gas property was in operation during the "base" period.

134. "In the case of natural gas companies, the nontaxable income from exempt excess output for any taxable year shall be an amount equal to the excess output for such year multiplied by one-half of the unit net income for such year." Ins. Rsv. Cons \$735(b) (5), added by Revenue Act of $1943, \S 208(c)$. "In respect of a natural gas property the term 'unit net income' means the amount ascertained by dividing the net income, computed in accordance with regulations prescribed by the Commissioner with the approval of the Secretary, from such property during the tasable year by the number of natural gas units sold in such year." INT. REv. CODE, $\$ 735(a)(12)$, amended by Revenue Act of $1943, \S 208$ (b) (3).

135. The industry as a whole earned only approximately four par cent on the total investment. See Miemorandum of the Natural Gas Industry, which apgears in Hcarings Before Committee on Ways and Mcans on Rezenue Revisions of 1943, 78th Cong., 1st Sess. (1943) 724, 732.

136. See page 486 stspra. 
accord with the desire of Congress to grant effective relief from excess profits taxes. Failure to base relief on the relation of excess output to recoverable reserves ${ }^{137}$ is, also, in keeping with intent to afford relief in respect to income attributable to the activities of storage and transportation by pipe line in addition to income attributable to withdrawal of the gas.

The exemptions afforded by Congress to the mining, timber, and gas industries with respect to excess profits taxes seem of questionable wisdom. It may be conceded that the excess profits of these industries are attributable, not to increased unit prices, but solely to increased output and that irreplacable "stock in trade" is depleted at an accelerated rate in times of high taxation. Viscerally viewed, however, no economic difference exists between taxing profits derived from higher per unit net income and taxing profits derived from increased production at a stable per unit profit. The conversion of the industries' stock in trade during times of high taxes hardly seems sufficient grounds for affording special treatment. All of the affected industries have available to them deductions from gross income based on percentage depletion. ${ }^{138}$ It cannot, therefore, be successfully disputed that only excessive profits are taxed.

In the case of the natural gas industry, where useful life of transportation facilities has a direct relation to the life of the reserves which the facilities serve, peacetime depreciation rates may well need adjustment. But this may be done administratively without special legislation. ${ }^{130}$ With the safeguards of the deductions for depletion and for depreciation - the latter adjusted to reflect the more rapidly approaching obsolescence of facilities whose useful lives are geared to the life of the resource which is being depleted ${ }^{140}$-it seems doubtful that confiscatory taxation would actually materialize or funded debts become in default.

137. It was argued that relief granted to natural gas companies should not be based upon the relation of excess output to recoverable reserves because:

". . . first, the rate of exhaustion of a natural gas property does not depend merely on the rate of withdrawal from taxpayer's property alone, but on the rate of withdrawal from all properties in the field, including properties of other interests; second, that the conditions indicative of normal or excess profits in the case of a natural gas company can best be determined for the company as a whole, rather than by properties; third, that the entire increased output compared with output in normal commercial years represents the forced using up of its nonreplaceable capital assets during an emergency period." Hearings Before Committec on Ways and Means on Revenue Revision of 1943, 78th Cong., 1st Sess. (1943) 733.

138. See page 471 et seg. supra.

- 139. Section 23 of the Internal Revenue Code provides: "Iin computing net income there shall be allowed as deductions: . . . (1) . . . a reasonable allowance for the exhaustion, wear and tear of property used in the trade or business, including a reasonable allowance for obsolescence. . . ." (Italics supplied).

140. For authority for such a stepped-up depreciation deduction, see Lassen Lumber \& Box Co. v. Blair, 27 F. (2d) 17 (C. C. A. 9th, 1928). 
Moreover, the formulae provided by Congress for determining the relief which is to be accorded the favored industries are almost certain to produce complicated administrative problems and litigation. Determination of the recoverable content of mineral deposits must be made, and in many instances such determinations will be inaccurate, leading to uncertainty and confusion. ${ }^{141}$

Cost accounting systems of a highly sensitive nature will be reguired to determine the net income attributable to the excessive output in the case of many mining companies where two or more metals or non-mutallic substances, or one or more metals or non-metallic substances and coal, exist in the minerals extracted from mining property, and in the case of integrated natural gas companies engaged in distribution as well as withdrawal, storage, and transportation of natural gas. A product-by-product cost accounting system cannot often be developed on anything mure than purely arbitrary assumptions, which will not be made by the Commissioner of Internal Revenue and the taxpayer with any degree of similarity. Congress might well have left the natural resources industries to wisely administered depletion and depreciation deductions.

\section{Excess Profits Tax Exejiption of Air Mi.in Carriers}

Congress, with a comprehensive legislative draft, the Civil Aeronautics Act of 1938, ${ }^{142}$ has prescribed complete regulation for commercial air transportation. ${ }^{143}$ Working from the premise that adequate service by commercial air carriers at reasonable charges could not be accomplished without financial aid from the federal government, ${ }^{114}$ the Act, in Title IV, adopts a subsidy system administered through payments made for carrying the mails. The Civil Aeronautics Board, ${ }^{145}$ which the Act establishes, is directed to determine how much income each air carrier subject to the provisions of Title IV of the Act should receive in order to enable it to acquire and maintain facilities and equipment necessary

141. Section 735(a) (10) of the Internal Revenue Code makes such estimate subject to the approval of the Commissioner of Internal Revenue and provides, further, that his determination shall be final and conclusive.

142. 52 Stat. 973 (1938), 49 U. S. C. $\$ \$ 201-682$ (1940). For a general diseussion of this legislation, see Legis. (1938) 52 HaRv. L. Rev. 137.

143. The Act also provides for control of private flying.

144. See Interstate Commerce Commission survey, Air-Mlail Compensaticn, 205 I. C. C. 675,707 (1935) ; Joint Hearings Before Commillee or: Wrays ard Mcans and Committee on Fintante, 76th Cong., 3d Sess. (1940) 182, 186. See also the Act's Declaration of Policy, 52 Stat. 977,980 (1938), 49 U. S. C. $\$ 402$ (1940).

145. The Board was originally designated Civil Aeronauties Authority: The .iuthurity and its functions were transierred to the Department of Commerce, and it was redesignated Civil Aeronautics Board by Reorganization Plan No. IV, $\$ 7$, effective June 30, 1940, 54 Stat. 1235 , 5 Fed. REg. 2421 (1940). 
to provide service adequate for the nation's commerce and defense, and to pay to the carrier in the form of compensation for carrying the mails the difference between this amount and the carrier's other commercial revenue. ${ }^{146}$ Since mail pay comprises about one-third of the nation's air carriers' total revenues, ${ }^{147}$ the Board through this subsidy system effectively controls the profits of air carriers subject to the provisions of Title IV of the Act.

When in 1940 Congress came to consider the draft of an excess profits tax law, it was urged that if air carriers whose incomes were subject to control by the Civil Aeronautics Board were also made subject to the excess profits tax, two profit-limiting enactments with conflicting norms would result. ${ }^{148}$

Persuaded by this argument, Congress exempted from excess profits taxation those corporations which were subject to the provisions of Title IV of the Civil Aeronautics Act of 1938 and received compensation from the United States for transporting the mails, provided no excess profits resulted from their ordinary commercial revenues. ${ }^{149}$ This plan left to the Civil Aeronautics Board the work of effectively curbing war profits of the air transport industry. ${ }^{150}$

The exemption covered the air carrier only if its excess profits net income is zero or less after compensation received from the United States for carrying the mails has been excluded from its gross income. ${ }^{151}$ Thus,

146. Specifically, the Act directs the Civil Aeronautics Board to fix different rates of mail pay for different air carriers, and in determining the rate in each case to consider, among other factors, "the need of each such carrier for compensation for the transportation of mail sufficient to insure the performance of such service, and, together with all other revenue of the carrier, to enable such carrier, under honest, economical and efficient management, to maintain and continue the development of air transportation to the extent and of the character and quality required for the commerce of the United States, the Postal Service, and the national defense." 52 StAT. 973, 998 (1938), 49 U. S. C. \&486(b) (1940). The amount needed to cure the carrier's deficiency in revenues as determined by the Board is divided by the number of units of mail carried and the rate per unit thus determined. See Joint Hearings Before Committee on Ways and Means and Contmittce on Firance, 76th Cong., 3d Sess. (1940) 190.

147. See Joint Hearings Before Committee on Ways and Means and Commilte on Finance, 76th Cong., 3d Sess. (1940) 177.

148. See id. at 178.

149. INT. Rev. Code $\$ 727$ (h) (Supp. 1941). The exemption appeared first in the Excess Profits Tax Act of 1940, 54 STAT. 974, 988 (1940), adding sub-chapter E to INT. REv. CoDE, c. 2, $\$ 727$ (h) (1939).

150. It may be noted that the control of the Civil Areonautics Board over profit of air carriers under the mail subsidy is immediate and direct, whereas economic regulation exercised by most state and federal regulatory commissions over other utilities, involving classical techniques of rate-making, is indirect and may often be ineffectual because of the uncertainty of business volume generated by the rate fixed.

151. Section 727 of the Internal Revenue Code, prior to its amendment by section 209 of the Revenue Act of 1943, provided: 
in determining whether or not it was exempt, the carrier was required to compute its adjusted excess profits net income by applying its excess profits credit and specific exemption against its excess profits net income. ${ }^{152}$ This method prevented the use of air mail compensation as a reducing factor in determining whether the carrier had any unused excess profits-credit for the year ${ }^{163}$ which might be used as a carry-back or carry-over to reduce excess profits net income for prior or subsequent years. ${ }^{154}$

In the Revenue Act of 1943, Congress broadened the exemption afforded air carriers by providing that the exclusion of air mail compensation shall also be made in determining the amount of the unused excess profits credit for such year available as an offset to adjusted excess profits net income in other taxable years. To the extent, however, that the unused excess profits credit adjustment is attributable to the exclusion of mail pay, it is available to the carrier solely for the purpose of applying the test of exemption. The touchstone under the amended law is whether the unused excess profits credit adjustment coupled with the exclusion of mail pay for the current year produces a zero adjusted excess profits net income. ${ }^{155}$ The amendment was made effective as though it were a part of the original exemption provision enacted in $1940 .{ }^{150}$

It is to be noted that the exemption applies to the corporation. It does not relieve air mail compensation from excess profits taxes, should it be found that under the test provided, the carrier is not an exempt corporation. The provision merely uses air mail compensation as a measuring

\footnotetext{
"The following corporations . . . shall be exempt from the tax imposed by" this subchapter:

"(b) Any corporation subject to the provisions of Title IV of the Civil Aeronautics Act of 1938, in the gross income of which for any tasable year beginning after December 31, 1939, there is includable compensation received from the United States for the transportation of mail by aircraft if, after excluding from its gross income such compensation, its adjusted excess profits net income for such year is zero or less."

152. INT. REv. CoDE $\$ 710$ (b) (Supp. 1941).

153. INT. Rev. CoDE $\$ 710$ (c), added by 55 Star. 17, Revenue Act of 1941 .

154. INr. REv. CODE $\$ 710$ (b) (3) (Supp. 1941). The following illustration will serve to clarify the operation of the exemption: Assume that $M$ Company, an air carrier transporting mail, other cargo, and passengers, with an excess profits credit of $\$ 50,000$, recsives gross income from all sources during 1942 in the amount of $\$ 500,000$, of which $\$ 300,000$ was received from carrying the mail. .M's gross income with mail pay excluded, $\$ 200,000$, is reduced by operating expenses which total $\$ 250,000$, leaving it a net loss, after exeluding compensation for carrying mail, in the amount of $\$ 30,000$. The company's excess profit credit, $\$ 50,000$, and specific exemption, $\$ 5,000$, are then added to the loss and an adjusted excess profits tax net income of minus $\$ 105,000$ is determined. The corporation is accordingly exempt from the excess profits tax.

155. See H. R. Conference Rep. No. 864, 7Sth Cong., 1st Sess. (1943) 2. Thus if, in the illustration given in note 154 supra, MPs gross income for 1943 were $\$ 1,000,000$,
} 
stick in determining whether the particular air mail carrier is to receive economic regulation from the tax laws or the Civil Aeronautics Board. The amendment contained in the 1943 Act lengthens the measuring stick in certain instances and seems in keeping with the policy of the original exemption, that two profit-limiting norms should not be outstanding at the same time.

\section{Conclusion}

As tax rates climb, Congress has shown increasing awareness of the commonplace principle that taxes which are very high should also be very ' fair. It has not been attempted here to deal with all the changes in existing revenue laws made by the Revenue Act of 1943, but it should be stated that the new law contains many provisions which operate adversely to the taxpayer remedying defects which have allowed undesirable tax avoidance. ${ }^{157}$ Except for those provisions which were designed to achieve increased war production - the temporary extension of the benefits of percentage depletion and the exemption from war profits taxation of income attributable to excessive production-the Act achieves a well considered balance between the weight of a desire to do substantial equity to taxpayers and pressure from the public treasury for an increased income over that provided by the existing revenue system.

its compensation for carrying the mail $\$ 500,000$, and operating expenses $\$ 400,000$, the company would be exempt under the amended law as follows:

\begin{tabular}{|c|c|c|}
\hline 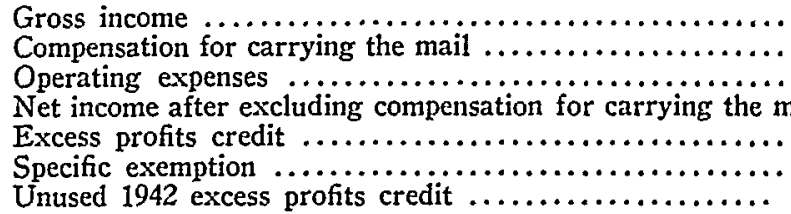 & $\begin{array}{r}\$ 50,000 \\
5,000 \\
50,000\end{array}$ & $\begin{array}{r}\$ 1,000,000 \\
500,000 \\
400,000 \\
100,000\end{array}$ \\
\hline profits net income & & \\
\hline
\end{tabular}

Since the company's adjusted excess profits net income without carry-over of the unused 1942 excess profits credit is $\$ 45,000$, it would not be exempt except. for the amendment in the 1943 Act, which is made retroactive so as to apply to all years governed by the present excess profits tax.

156. Revenue Act of $1943, \S 209$ (b).

157. The chief tax avoidance prophylactic is a provision which eliminates any tax benefit from the acquisition of corporate shares or property carrying losses, deficits, or unused excess profits credits for the purpose of reducing income and excess profits taxes. Revenue Act of $1943, \S 128$. Other provisions unfavorable to the taxpayer: repeal of the earned income credit, $\$ 107$ (a); federal import duties and excise and stamp taxes made no longer deductible as taxes, though still deductible as business expenses or expenses for the production of income or maintenance of property, $\S 111$; the so-called Field Amendment, limiting deductions for losses sustained in a business enterprise, if it has operated at a loss for five consecutive years, $\S 129$; limitation on foreign tax credits of corporaltions to allow the credit at no higher average rate than those imposed by the United States, $\S 130$. 